\title{
Why the Donkey Did Not Go South: Disease as a Constraint on the Spread of Equus asinus into Southern Africa
}

\author{
Peter Mitchell $\mathbb{D}$
}

Published online: 9 March 2017

(C) The Author(s) 2017. This article is published with open access at Springerlink.com

\begin{abstract}
Donkeys are the only ungulate definitely known to have been domesticated in Africa and were widely employed in the north of the continent and through the Sahara and the Sahel as pack animals, as well as spreading through much of the Old World. Used in Egypt by 4000 BC, they are attested in Nubia in the third millennium BC, in eastern Sudan in the second millennium $\mathrm{BC}$ and, in a Pastoral Neolithic context, at Narosura, Kenya, in the first millennium BC. However, they went completely unremarked by early European observers in southern Africa and appear never to have reached that region, unlike cattle and sheep, both of which reached it before the beginning of the Christian era in a process that linguistic and genetic data now firmly link to the migration of herders from East Africa. Taking its lead from previous studies of the impact of epizootic disease on the expansion through Sub-Saharan Africa of cattle and dogs, this paper asks if disease also constrained the southward movement of donkeys and, if so, what the consequences of this may have been.
\end{abstract}

Résumé Les ânes sont les seules ongulés certainement connus pour avoir été domestiqués en Afrique et ont été

P. Mitchell $(\bowtie)$

School of Archaeology, University of Oxford, Oxford OX2 6LE, UK

e-mail: peter.mitchell@arch.ox.ac.uk

\section{P. Mitchell}

School of Geography, Archaeology and Environmental Studies, University of the Witwatersrand, Johannesburg PO Wits 2050, South Africa largement utilisés dans le nord du continent et à travers le Sahara et le Sahel comme animaux de bât, ainsi qu'ils se sont diffuses à travers une grande partie de l'Ancien Monde. Utilisés en Egypte par 4000 av. J.-C., ils sont attestés en Nubie dans le troisième millénaire avant J.-C. dans l'est du Soudan dans le deuxième millénaire avant J.C. et dans un contexte Néolithique pastoral au Narosura, au Kenya, au cours du premier millénaire avant notre ère. Cependant, les premiers observateurs européens en Afrique méridionale ne nous en donnent aucune mentione et il semble donc que les ânes n'y sont jamais arrivés, une situation très differente de celle du bétail et des moutons, qui ont atteint l'Afrique méridionale avant le début de l'ère chrétienne dans un processus pour lequel les données linguistiques et génétiques maintenant soutiennent un fort lien à la migration des éleveurs originant en Afrique orientale. Prenant son avance des études précédentes de l'impact de les maladies épizootiques sur l'expansion à travers l'Afrique sub-saharienne du bétail et des chiens, cet article demande si les maladies ont également contraint le déplacement vers le sud des ânes et, si oui, quelles sont les conséquences de ceci.

Keywords Donkeys · Africa · Pastoralism · Infectious disease $\cdot$ Trypanosomiasis $\cdot$ Equine piroplasmosis . African horse sickness

\section{Introduction}

Relative to Eurasia, Africa is the original home of very few of the world's domesticated mammals. Claims for a 
separate early Holocene domestication of cattle (Bos taurus) are disputed on both osteological and genetic grounds (di Lernia 2013; Stock and Gifford-Gonzalez, 2013), although some input from African individuals is likely once cattle arrived in Northeast Africa from the Near East (Pérez-Pardal et al. 2010), followed by further admixture with ultimately South Asian-derived zebu (Bos indicus) in and after the Bronze Age (Hanotte et al. 2000). Cats (Felis catus) have also been considered an African domesticate based on their strong archaeological presence in Pharaonic Egypt, but while tamed as early as the late Predynastic period (Van Neer et al. 2014), genetic and archaeological data now also point to another (and earlier) domestication event in the Near East (O'Brien et al. 2008). This leaves donkeys (Equus asinus) as the only domestic mammal for which a uniquely African centre of origin can still plausibly be argued (Kimura et al. 2013), although even then southwestern Arabia may have been an additional domestication locus (Rosenbom et al. 2014).

Recent research has emphasised that early pastoralists in Northeast Africa likely found African wild asses (Equus africanus) increasingly useful as a substitute for cattle in moving water, firewood and their own possessions as climate became drier in the middle Holocene. Asses are not only adapted to hot, dry conditions, but also need less food, can digest coarser grasses and have several important water-sparing adaptations (Kimura et al. 2013). Significant morphological change may have taken some considerable time to appear, with osteological damage caused by carrying heavy loads a more certain indicator of domestication than reduction in size (Rossel et al. 2008). The archaeozoological record nevertheless indicates that donkeys were in use in Egypt and had spread into the Near East by the onset of the third millennium $\mathrm{BC}$, occurred widely in Sudan by the following millennium and had reached southern Kenya/northern Tanzania and the central Sahara by or soon after 3000 years ago. In all of these contexts, they are associated with human populations who also kept cattle and caprines.

However, while other species of domestic livestock underwent a significant further expansion as far as southern Africa in the last couple of centuries BC (Orton 2015) and were subsequently kept there in large numbers by both Khoe-speaking herders and (from the middle centuries of the first millennium AD) Bantuspeaking agropastoralists (Huffman 2007; Sadr 2013), donkeys remained behind in East Africa. Unless this is the result of widespread taphonomic bias, given their many advantages for East African pastoralists today, their widespread utility for more settled, agricultural populations in the Sahel, North Africa and beyond and their presence in East Africa before herders spread south from there, this requires explanation.

Earlier research that explored the possible roles of infectious diseases in constraining the spread within Sub-Saharan Africa of both cattle (GiffordGonzalez 2000, 2016) and dogs (Mitchell 2015) suggests that this may be a productive line of enquiry for explaining why donkeys did not expand into southern Africa in precolonial times. Indeed, Blench (2000, p. 350) noted some time ago that in recent times "the clearing of savanna forest of the Sahel and the consequent decline in tsetse challenge has permitted donkeys to spread southwards" in West Africa [emphasis added]. To investigate the possible role of disease, I first review the archaeological and historical evidence for the donkey's presence in Northeast and East Africa and the subsequent southward spread of other livestock taxa. I then show that there is no historical or archaeological evidence for donkeys having been present in southern Africa before European settlement. To understand this, I look at three disease challenges - trypanosomiasis, equine babesiosis/piroplasmosis and African horse sickness-discussing their epidemiology, pathology and current distribution. While these infections may not on their own account for the donkey's absence from southern Africa, I argue that the dangers they pose to $E$. asinus require us to include them in any explanation of the latter's otherwise curious omission from the domestic animals kept there by precolonial African populations.

Origins and Spread of the Donkey in Sub-Saharan Africa

Genetic studies have thrown considerable new light on the origins of donkeys and consistently divide them into two evolutionary groups. Conventionally named clades I and II, they are found across the world in roughly equal proportions without any clear geographic pattern (Kimura et al. 2013). Clade I is closely related to the Nubian wild ass (E. africanus africanus), one of two surviving but genetically well-separated subspecies of the African wild ass (Beja-Pereira et al. 2004; Kimura et al. 2011). However, thus far, it has not been possible 
Table 1 Early archaeological occurrences of domesticated donkeys (Equus asinus) in Northeast, Saharan and East Africa (after Marshall 2007; directly dated specimens have their dates given in italics)

\begin{tabular}{|c|c|c|c|}
\hline Country & Site & Date & Reference \\
\hline Egypt & El Omari & $4600-4400$ cal. BC & Boessneck and von den Driesch (1998) \\
\hline Egypt & Maadi & $4000-3500$ cal. BC & Boessneck von den Driesch and Ziegler (1989) \\
\hline Egypt & Hierakonpolis & 3600 cal. BC & Van Neer et al. (2004) \\
\hline Egypt & Naqada & Predynastic & Gautier and Van Neer (2009) \\
\hline Egypt & Elephantine & Predynastic & Hollmann (1990) \\
\hline Egypt & Buto & Predynastic/Old Kingdom & von den Driesch (1997) \\
\hline Egypt & Tell el-Farkha & $3100-3000 \mathrm{BC}$ & Dębowska-Ludwin (2012) \\
\hline Egypt & Abydos & $3000 \mathrm{BC}$ & Rossel et al. (2008) \\
\hline Egypt & Helwan & $3000-2700 \mathrm{BC}$ & Flores (2003) \\
\hline Egypt & Tarkhan & $\begin{array}{l}\text { ca. } 3000-2850 \text { BC } \\
4390 \pm 130 \text { BP }(\mathrm{OxA}-566) \\
3497-2670 \text { cal. } \mathrm{BC}\end{array}$ & Burleigh et al. (1991) \\
\hline Egypt & Abusir & ca. $2950 \mathrm{BC}$ & Boessneck et al. (1992) \\
\hline Sudan & Kerma & Third millennium cal. BC & Chaix (1993) \\
\hline Sudan & Wadi Hariq & $\begin{array}{l}3560 \pm 150 B P(\mathrm{KN}-5318) \\
2340-1527 \mathrm{cal} . \mathrm{BC}\end{array}$ & Jesse et al. (2004) \\
\hline Sudan & Mahal Teglinos & $1700-1400 \mathrm{BC}$ & Gautier and Van Neer (2006) \\
\hline Sudan & Shaqadud & $2200-1700$ cal. BC & Peters (1991) \\
\hline Eritrea & Pwnt & ca. $1460 \mathrm{BC}$ & Houlihan (2002) \\
\hline Libya & Uan Muhuggiag & $1211-1026 \mathrm{cal} . \mathrm{BC}$ & Kimura et al. (2011) \\
\hline Kenya & Narosura & $1300-200$ cal. BC & Gifford-Gonzalez and Kimengich (1984) \\
\hline Tanzania & Jangwani 2 & ca. $1000 \mathrm{BC}-\mathrm{AD} 500$ & Prendergast and Mutundu (2009) \\
\hline Tanzania & Gileodabeshta 2 & 1100 BC-ca. AD 500 & $\begin{array}{l}\text { Prendergast and Mutundu (2009) } \\
\text { Prendergast et al. (2014) }\end{array}$ \\
\hline Ethiopia & Mezber & First millennium cal. BC & D’Andrea et al. (2011) \\
\hline Sudan & Gala Abu Ahmed & $900-400 \mathrm{BC}$ & Linseele and Pöllath (2015) \\
\hline Senegal & Cubalel & ca. $\mathrm{AD} 1-400$ & MacDonald and MacDonald (2000) \\
\hline
\end{tabular}

to establish the ancestry of clade II, except to exclude from consideration the other extant subspecies, the Somali wild ass (Equus africanus somaliensis) (Kimura et al. 2011). This is consistent with a lack of evidence for this subspecies hybridising with domestic donkeys (Kebede 2013). A now extinct wild relative of both subspecies is a not-unlikely alternative ancestor for clade II (Kimura et al. 2013, p. 89).

Table 1 lists the earliest archaeological evidence for the domesticated donkey in Northeast, East and Saharan Africa (based largely on Marshall 2007, Table 20.2). Difficulties in discriminating donkeys from wild equids where faunal remains are fragmentary, the fact that they are generally kept for transport not food (so that their bones may not accumulate) and potential variability in kraaling practices on what are likely to be quite ephemeral campsites may all impair their recognition in the archaeozoological record, while changes in bone morphology diagnostic of load-bearing have only rarely been sought (Marshall and Weissbrod 2009; Shackelford et al. 2013). Nevertheless, the general pattern indicated by Table 1 and illustrated in Fig. 1 is likely to be robust.

The oldest archaeological examples of domestic donkeys come from Predynastic and Archaic Egypt, with the earliest at El Omari in contexts dated to 4600-4400 cal. BC (Boessneck and von den Driesch 1998), followed by others at a number of sites in both Upper Egypt and the Nile Delta (e.g., Van Neer et al. 2004; DębowskaLudwin 2012). Iconographic representations - notably 


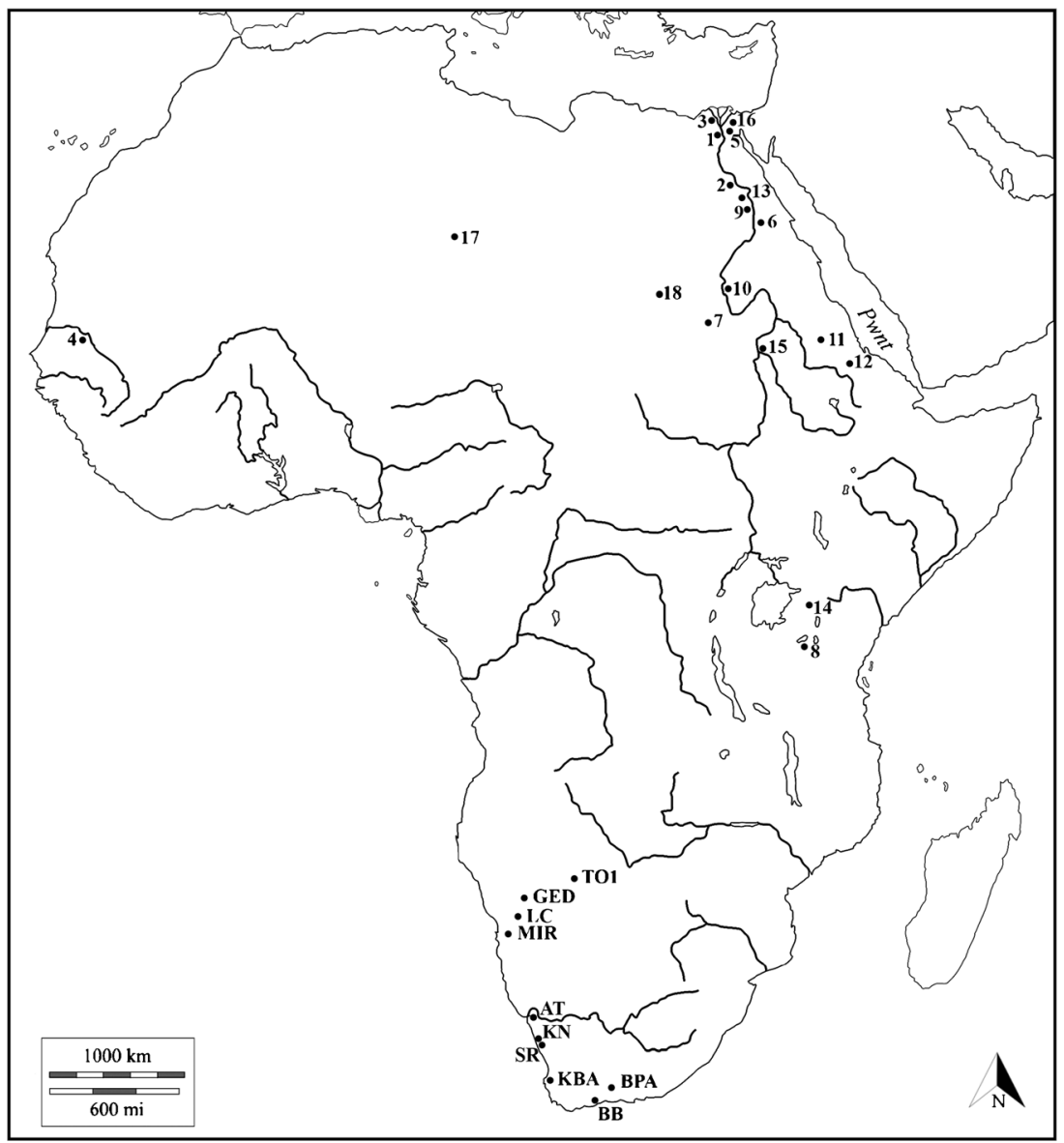

Fig. 1 Africa showing the location of the early archaeological occurrences of donkeys listed in Table 1 and those of early $(>1500$ BP) occurrences of domestic sheep and cattle south of the Zambezi listed in Table 4 that reflect the spread of pastoralism into southern Africa from East Africa. Sites producing early donkey remains are numbered as follows: 1 Abusir, Tarkhan; 2 Abydos; 3 Buto; 4 Cubalel; 5 El Omari, Helwan, Maadi; 6 Elephantine; 7 Gala Abu

on the Libyan Palette (Dochniak 1991) - are also known. Deliberate interments with elite associations dated to the First Dynasty or shortly thereafter come from Abydos in Upper Egypt (Rossel et al. 2008) and three sites near Memphis, just south of Cairo: Abusir (Boessneck et al. 1992), Helwan (Flores 2003) and Tarkhan (Burleigh et al. 1991). There is then considerable epigraphic and iconographic evidence for the employment of donkeys in agricultural activities and as pack animals in the Old Kingdom and all subsequent periods of Pharaonic history (e.g., Closse 1998; El-Menshawy 2009). Donkeys were also used to facilitate Egyptian expeditions into the Western Desert, reaching up to at least $600 \mathrm{~km}$ west of the Nile as
Ahmed; 8 Gileodabeshta 2, Jangwani 2; 9 Hierakonpolis; 10 Kerma; 11 Mahal Teglinos; 12 Mezber; 13 Naqada; 14 Narosura; 15 Shaqadud; 16 Tell el-Farkha; 17 Uan Muhuggiag; and 18 Wadi Hariq. Sites in southern Africa with early occurrences of domestic livestock are abbreviated as follows: ATAi tomas, $B B$ Blombos Cave, BPA Boomplaas, GED Geduld, KBA Kasteelberg A, KN KN2005/ 041, LC Leopard Cave, MIR Mirabib, SR Spoegrivier, TO1 Toteng 1

early as 2600 BC (Kuper 2006; Förster 2013) and were introduced into the Near East from around 3000 BC (Grigson 2006).

The archaeozoological record for donkeys along the Middle Nile and elsewhere in northeastern Africa is patchier. Several finds document their presence at Kerma from the third millennium $\mathrm{BC}$ (Chaix 1993), and a complete skeleton has been directly dated to $3560 \pm 150$ BP (KN-5318, 23401527 cal. BC at $95 \%$ probability using IntCal13) from a pastoralist (Handessi Horizon) context at Wadi Hariq, $400 \mathrm{~km}$ west of the Nile (Jesse et al. 2004). Still further into the Sahara, donkeys were present in southwestern Libya by $1000 \mathrm{BC}$ 
(Kimura et al. 2011) and had expanded beyond the southern limits of the desert into the Sahel by the early centuries $\mathrm{AD}$ (MacDonald and MacDonald 2000). East of the Nile the Gash Delta has produced remains dated to the second millennium $\mathrm{BC}$ (Gautier and Van Neer 2006), broadly contemporary with representations of donkeys in the land of Pwnt (probably equivalent to the coast of northern Eritrea) in the reliefs of Queen Hatshepsut's funerary temple at Deir el-Bahri ca. $1460 \mathrm{BC}$ (Houlihan 2002, p. 124). The oldest archaeological specimens from Eritrea/Ethiopia are younger than this, however, and come from Pre-Aksumite contexts of the first millennium BC at Mezber (D'Andrea et al. 2011), followed by later examples at and near Aksum itself in the first millennium AD (Cain 1999; Chaix 2013). Also of first millennium $\mathrm{BC}$ date are finds from Napatan contexts at the fortress of Gala Abu Ahmed in Wadi Howar, $110 \mathrm{~km}$ west of the Nile (Linseele and Pöllath 2015, p. $566)$, although donkeys are rare in other Kushite sites (Chaix 2008).

Within East Africa, donkey teeth are known from Narosura, southwestern Kenya (Gifford-Gonzalez and Kimengich 1984, p. 470; Marshall 2007, p. 385), in Pastoral Neolithic contexts dated to the first millennium BC (Odner 1972). Their identification seems secure as it reflects the independent assessment of two of the region's leading archaeozoologists. Marshall (2000, Table 10.3) also notes the presence of donkeys at the first millennium BC Elmenteitan site of Ngamuriak, also in southwestern Kenya, but they are not reported in her detailed analysis of its fauna (Marshall 1990, p. 211). They do, however, occur at Jangwani 2 and Gileodabeshta 2 in the Lake Eyasi Basin of northern Tanzania. While both sites have undergone a degree of bioturbation and some of the radiocarbon dates from them are suspect, only Pastoral Neolithic (mostly Narosuran) ceramics were recovered and a first millennium $\mathrm{BC} /$ earlier first millennium $\mathrm{AD}$ date is plausible (Prendergast and Mutundu 2009, p. 219). Recent direct dating of a Narosuran sherd from Gileodabeshta 2 to $2910 \pm 20$ BP (1126-929 cal. BC, ISGS-A2368) strengthens this interpretation (Prendergast et al. 2014).

Documentary references from the nineteenth and twentieth centuries nevertheless make it plain that donkeys had a limited presence in East Africa as a whole during and immediately before the colonial era, a situation that has only recently begun to change. In Kenya and Tanzania, they were effectively confined to those arid and semiarid areas where pastoralism was a major activity and were virtually absent toward the Great Lakes and from the southern lowlands of Tanzania (Wilson 2013). They may, however, have been kept in Swahili settlements along the Tanzanian and Kenyan coast, having been introduced from southern Arabia or elsewhere in the Middle East (Blench 2000). Further south, donkey numbers in Central and south-central Africa are extremely low today, although showing some increase, for example in Malawi and Zambia, as part of ongoing development initiatives (Starkey and Starkey 2004). Nowhere in these regions, however, is there any suggestion that they were present before the advent of Europeans. Indeed, in July 1866, David Livingstone noted in his diary when approaching Lake Malawi from the east that local residents greeted his one remaining donkey (brought south from Zanzibar) with as much curiosity and laughter as they did himself (Wilson 2013, p. 39).

\section{Donkeys in Southern Africa?}

Much of south-central Africa (southern Tanzania, Malawi, Zambia) is not propitious for cattle due to the presence of a range of serious infectious diseases, particularly trypanosomiasis (Gifford-Gonzalez 2000), and many local populations, such as the Bemba (Richards 1939) and Yao (Mitchell 1963), consequently did not keep them. Cattle and caprines did, however, pass through these areas to form a cornerstone of herder and agropastoralist economies in much of Africa south of the Zambezi. Might the same have been true of donkeys?

From a historical standpoint, the answer seems to be a definitive no. Dent (1972, p. 123), for example, is unequivocal in stating that "there were no asses in southern Africa until the arrival of the Dutch" in the seventeenth century, while Jacobs (2001, p. 485) is equally categorical: "Donkeys are not indigenous to South Africa...they arrived through European expansion." Lying behind these statements are the observations of numerous European explorers, scientists and other observers from 1488, when the Portuguese first skirted southern Africa's Atlantic coast, into the nineteenth century. None found any difficulty in noting that the Khoe-speaking herders living in the more arid western third of the subcontinent kept large numbers of sheep and cattle, along with some goats, or that Bantuspeaking agropastoralists further east did the same 
wherever the absence of disease made this possible. However, not one historical observation exists of even a single donkey in indigenous hands (e.g., Kolbe 1731; Schapera and Farrington 1933; Mossop 1935; Thom 1952, 1954, 1958; Burchell 1953; Thompson 1967, 1968; Raven-Hart 1971; Valentyn 1971, 1973; Smith 1975; Sparrman 1975, 1977; Thunberg 1986). Moreover, the only references to "wild horses and mules" explicitly note that they were covered with stripes (e.g., Schapera and Farrington 1933, p. 33), an unambiguous indicator that the animals in question were, in fact, zebras. Given that European observers, including scientists of international repute such as Anders Sparrman, Carl Peter Thunberg and William Burchell, were so unanimous in not mentioning the presence of donkeys among southern African herders and farmers, while having no difficulty in commenting on the presence of equally familiar cattle, sheep, goats and dogs, it seems reasonable to conclude that donkeys were not kept by native southern African populations at the time of European contact.

But might they have reached southern Africa from further north only to die out before European arrival? An answer to this question can only be provided by archaeozoology and, as noted above, the likelihood of finding donkey remains in archaeological sites is low where they were not regularly eaten or given special treatment such as deliberate, ritualised burial (e.g., Rossel et al. 2008; Way 2011). Distinguishing donkeys from other equids on the basis of their faunal remains is also not straightforward unless preservation of dentition or long bones is good (Marshall 2007, p. 379; cf. Johnstone 2004). It is therefore conceivable that donkeys might have been present in the flesh, but still be absent from, or go unrecognised in, archaeozoological assemblages, especially in the absence, thus far, of projects that are not specifically geared toward equid identification. It is certainly true that faunal assemblages in southern Africa are often not large and that the likelihood of a rare (and potentially unexpected) taxon turning up in them may thus be low. However, even at key sites that have produced evidence of early herding or in extremely large agropastoralist-associated faunal assemblages, donkeys are conspicuously absent and equids as a whole, rare (Table 2). Overviews of farmer community (Iron Age) archaeozoological studies such as that provided by Plug and Voigt
(1985) and Plug (1996) reinforce this conclusion for southern Africa as a whole.

Moreover, two compelling arguments exist against the possibility that donkeys were present, but have not yet been archaeozoologically identified, in precolonial southern Africa. First, donkeys have been recognised in a very small number of nineteenth-century contexts where the same taphonomic biases presumably apply and where horse and/or zebra are also present or might be expected (Plug and Badenhorst 2001, p. 97; Table 3). It thus seems unlikely that differential identification is a major issue. Second, if donkeys were present in southern Africa at some point, but did not preserve, or have not yet been recognised, in faunal assemblages of precolonial age, then we would have to explain why theyand they alone of the domestic animals that could have been brought to southern Africa by populations originating north of the Zambezi-disappeared. Occam's razor surely dictates instead that the lack of donkey bones in precolonial southern African sites is consistent with the species' absence from fifteenth- to nineteenth-century European accounts of indigenous communities and that the two facts together are congruent with donkeys having been first introduced by the Dutch in 1689, as historical records attest (Boettger 1958). Thereafter, they initially spread inland with European settlers and were originally restricted to South Africa but are now of considerable economic importance to poorer rural populations there and in Lesotho, Botswana, Zimbabwe and Namibia (Starkey and Starkey 2004).

If donkeys were not present in southern Africa, archaeological, historical and ethnographic evidence do all confirm that Khoe-speaking herders in South Africa and Namibia kept sheep cattle and goats (Sadr 2013), just like Bantu-speaking agropastoralists did in the better-watered parts of the subcontinent's summer rainfall region (Voigt 1986; Huffman 2007). In both cases, livestock and the milk that they produced were not only a core element of the diet but also essential to human social reproduction because of the powerful symbolic associations that they held (e.g., Huffman 1998; Lombard and Parsons 2015).

Cattle, sheep and goats all reached southern Africa by passing through the intermediate zone of miombo woodland savannas in south-central Africa, and for cattle and sheep, in particular, their only plausible source lies ultimately in the Pastoral Neolithic and Early Iron Age of East Africa (Smith 1992, 2005; Gifford-Gonzalez 
Table 2 Size of faunal assemblages at selected early herder sites and agropastoralist sites in southern Africa

\begin{tabular}{|c|c|c|c|c|c|}
\hline Country (province) & Site & $\begin{array}{l}\text { NISP/MNI (large } \\
\text { mammal) }\end{array}$ & $\begin{array}{l}\mathrm{NISP} / M N I \\
\text { (equids) }\end{array}$ & $\begin{array}{l}\mathrm{NISP} / M N I \\
\text { (donkeys) }\end{array}$ & Reference \\
\hline Botswana & Toteng 1 & 197 & - & - & Robbins et al. (2008) \\
\hline Namibia & Geduld & 215 & 13 & - & $\begin{array}{l}\text { Smith and Jacobson } \\
\text { (1995) }\end{array}$ \\
\hline Namibia & Leopard Cave & 44 & - & - & Pleurdeau et al. (2012) \\
\hline South Africa & Blombos & 1,665 & - & - & Henshilwood (2008) \\
\hline $\begin{array}{l}\text { South Africa (Western } \\
\text { Cape) }\end{array}$ & $\begin{array}{l}\text { Boomplaas (DGL } \\
\text { Member) }\end{array}$ & 87 & 3 & - & Klein (1978) \\
\hline $\begin{array}{l}\text { South Africa (Western } \\
\text { Cape) }\end{array}$ & Kasteelberg A & 3671 & - & - & $\begin{array}{l}\text { Klein and Cruz-Uribe } \\
\quad(1989)\end{array}$ \\
\hline $\begin{array}{l}\text { South Africa (Western } \\
\text { Cape) }\end{array}$ & Kasteelberg B & 17,856 & - & - & $\begin{array}{l}\text { Klein and Cruz-Uribe } \\
\text { (1989) }\end{array}$ \\
\hline Botswana & Bosutswe & 3882 & 87 & - & Denbow et al. (2008) \\
\hline South Africa (Limpopo) & $\mathrm{K} 2$ & 692 & 1 & - & Voigt (1983) \\
\hline South Africa (Limpopo) & Mapungubwe & 428 & 7 & - & Voigt (1983) \\
\hline
\end{tabular}

MNI figures (i.e., Minimum Numbers of Individuals) are given in italics

2000; Huffman 2007; Sadr 2013). A growing body of genetic and linguistic evidence points to livestock having been first introduced to northern southern Africa at the end of the first millennium $\mathrm{BC}$ as a result of a southward migration of people and animals, most likely from Tanzania (Güldemann 2008; Lombard 2014; Orton 2015; Table 4). Potential parallels in ceramics and stone bowls offer support for this from the realm of

Table 3 Donkeys in archaeozoological assemblages from southern Africa

\begin{tabular}{|c|c|c|c|c|}
\hline $\begin{array}{l}\text { Country } \\
\text { (province) }\end{array}$ & Site & $\begin{array}{l}\text { Date }(\mathrm{AD}) \text { of } \\
\text { context }\end{array}$ & NISP & References \\
\hline Lesotho & $\begin{array}{l}\text { Sehonghong } \\
\text { (Layer } \\
\text { GAP) }\end{array}$ & $\begin{array}{l}\text { ca. } 250-1000 \\
\text { (fresh; later } \\
\text { intrusion, } \\
\text { likely post- } \\
\text { 1878) }\end{array}$ & 1 & $\begin{array}{l}\text { Plug and } \\
\text { Mitchell } \\
\text { (2008) }\end{array}$ \\
\hline $\begin{array}{l}\text { South } \\
\text { Africa } \\
\text { (Eastern } \\
\text { Cape) }\end{array}$ & Haaskraal & ca. $1810-1870$ & 1 & $\begin{array}{l}\text { Voigt et al. } \\
\text { (1995) }\end{array}$ \\
\hline $\begin{array}{l}\text { South } \\
\text { Africa } \\
\text { (Kwa- } \\
\text { Zulu- } \\
\text { Natal) }\end{array}$ & Ondini & $\begin{array}{l}\text { 1873-1879 } \\
\quad \text { (later } \\
\text { intrusion?) }\end{array}$ & 1 & $\begin{array}{l}\text { Watson and } \\
\text { Watson } \\
(1990)\end{array}$ \\
\hline $\begin{array}{l}\text { South } \\
\text { Africa } \\
\text { (Limpo- } \\
\text { po) }\end{array}$ & $\begin{array}{l}\text { Steinaecker's } \\
\text { Horse }\end{array}$ & 1900-1902 & 1 & $\begin{array}{l}\text { Badenhorst } \\
\text { et al. } \\
\text { (2002) }\end{array}$ \\
\hline
\end{tabular}

material culture (Smith 1992). However, while cattle, sheep, goats and, indeed, dogs reached southern Africa, the one truly African domesticate - the donkey - did not. Since we know that donkeys were kept by at least some Pastoral Neolithic groups in East Africa and that it is to these groups and this area that we must look for the origin of southern Africa's precolonial domesticated animals, we need to ask why the donkey did not also go south. I suggest that one component of any answer to this question must involve disease.

\section{Disease Challenges for Donkeys}

Remnant populations of the donkey's ancestor, the African wild ass, survive today, but both of its subspecies are critically endangered. The Nubian wild ass is now probably extinct in the wild, while the Somali wild ass has undergone considerable reduction in numbers and definitely survives only in the Denkalia Desert of Eritrea and the Danakil Desert of Ethiopia, the situation in Somalia being unknown (IUCN 2015). A third likely subspecies, the Atlas wild ass (Equus africanus atlanticus), persisted in the Maghreb into Roman times, but is now extinct. Reconstructions of the likely original distribution within Africa of the species as a whole confine it to North Africa, the Sahara and the arid to semiarid regions of the Horn (Fig. 2). As Blench (2000, p. 340) and others have noted, "it is generally 
Table 4 Early archaeological occurrences of domesticated livestock in southern Africa (directly dated specimens are given in bold)

\begin{tabular}{|c|c|c|c|c|c|c|}
\hline Country & Site & Laboratory number & Date BP & $\begin{array}{l}\text { Calibrated } \\
\text { date }(95 \%)\end{array}$ & Species & Reference \\
\hline Namibia & $\begin{array}{c}\text { Leopard } \\
\text { Cave }\end{array}$ & Beta-270164 & $2270 \pm 40$ & 394-202 cal. BC & Caprine & Pleurdeau et al. (2012) \\
\hline Namibia & $\begin{array}{c}\text { Leopard } \\
\text { Cave }\end{array}$ & Beta-270163 & $2190 \pm 40$ & 358-67 cal. BC & Caprine & Pleurdeau et al. (2012) \\
\hline $\begin{array}{l}\text { South } \\
\text { Africa }\end{array}$ & Spoegrivier & OxA-3862 & $2105 \pm 65$ & $\begin{array}{l}353 \text { cal. BC-cal. } \\
\text { AD } 70\end{array}$ & Ovis aries & Sealy and Yates (1994) \\
\hline Botswana & Toteng 1 & Beta-1904888 & $2070 \pm 40$ & $\begin{array}{l}144 \text { cal. BC-cal. } \\
\text { AD } 60\end{array}$ & Bos taurus & Robbins et al. 2008) \\
\hline Botswana & Toteng 1 & Beta-186669 & $2020 \pm 40$ & $\begin{array}{l}61 \text { cal. BC-cal. } \\
\text { AD } 115\end{array}$ & Ovis aries & Robbins et al. (2008) \\
\hline $\begin{array}{l}\text { South } \\
\text { Africa }\end{array}$ & Ai tomas & Pta-5530 & $1980 \pm 120$ & $\begin{array}{l}349 \text { cal. BC-cal. AD } \\
\quad 364\end{array}$ & Ovis aries & Webley (1992) \\
\hline $\begin{array}{l}\text { South } \\
\text { Africa }\end{array}$ & $\begin{array}{l}\text { Blombos } \\
\text { Cave }\end{array}$ & OxA-4543 & $1960 \pm 50$ & $\begin{array}{l}48 \text { cal. BC-cal. AD } \\
211\end{array}$ & Ovis aries & Henshilwood (1996) \\
\hline $\begin{array}{l}\text { South } \\
\quad \text { Africa }\end{array}$ & $\begin{array}{l}\text { Blombos } \\
\text { Cave }\end{array}$ & OxA-4544 & $1880 \pm 55$ & cal. AD 47-340 & Ovis aries & Henshilwood (1996) \\
\hline Namibia & Geduld & Pta-4419 & $1790 \pm 80$ & cal. AD 75-470 & $\begin{array}{l}\text { Ovis aries } \\
\text { (dung) }\end{array}$ & Smith and Jacobson (1995) \\
\hline $\begin{array}{l}\text { South } \\
\text { Africa }\end{array}$ & Boomplaas & UW-338 & $1700 \pm 55$ & cal. AD 245-525 & Ovis aries & Deacon et al. (1978) \\
\hline $\begin{array}{l}\text { South } \\
\text { Africa }\end{array}$ & $\begin{array}{l}\text { Kasteelberg } \\
\text { A }\end{array}$ & OxA-3864 & $1630 \pm 60$ & cal. AD 340-628 & Ovis aries & Sealy and Yates (1994) \\
\hline $\begin{array}{l}\text { South } \\
\quad \text { Africa }\end{array}$ & $\begin{array}{l}\mathrm{KN} 2005 / \\
041\end{array}$ & OxA-22933 & $1625 \pm 25$ & cal. AD 414-540 & Bos taurus & Orton et al. (2013) \\
\hline Namibia & Mirabib & Pta-1535 & $1550 \pm 50$ & cal. AD 435-641 & $\begin{array}{l}\text { Ovis aries } \\
\text { (dung) }\end{array}$ & Sandelowsky et al. (1979) \\
\hline $\begin{array}{l}\text { South } \\
\quad \text { Africa }\end{array}$ & Boomplaas & UW-307 & $1510 \pm 75$ & cal. AD 415-681 & Ovis aries & Deacon et al. (1978) \\
\hline
\end{tabular}

All radiocarbon dates have been calibrated using OxCal 4.2 and the SHCal13 curve

considered unlikely that it ever occurred in sub-Saharan regions."

Much of the eastern, south-central and southern regions of sub-Saharan Africa, on the other hand, was, and remains, home to one or more other equid species. Three such taxa survive today: Grévy's zebra (E. grevyi) in the semi-arid grasslands of Ethiopia and northern Kenya; the plains zebra (E. quagga) from Kenya south into South Africa; and the mountain zebra (E. zebra) in the Western and Eastern Cape Provinces of South Africa and in Namibia. As in the analogous cases of cattle (GiffordGonzalez 2000) and dogs (Mitchell 2015), when domesticated equids entered areas south of the Sahara and the Horn to which they were strangers they may have encountered pathogens to which they had no prior experience. The susceptibility of domestic horses to diseases originally restricted to Africa south of the Sahara is well established, and trypanosomiasis and African horse sickness, in particular, severely constrained their expansion south of the
Sahel and in South Africa (Clutton-Brock 2000, pp. 3031; Swart 2010). What has not been considered until now is whether these diseases, or others, similarly hindered the expansion of the donkey.

Direct evidence of many infectious diseases is difficult to recover from the archaeozoological record, although the identification of tick vectors, such as the brown dog tick (Rhipicephalus sanguineus), in mummified dogs in Egypt (Hutchet et al. 2013), or of a range of parasites in dog coprolites from Peru (Richardson et al. 2012), indicates what is possible when preservation conditions are favourable. Recovery of parasite genetic material is also possible in some circumstances, as in the case of the DNA of Trypanosoma cruzi, which causes Chagas disease, retrieved from the rib of a well-preserved pre-Columbian person in Brazil (Lima et al. 2008). Pending similar exceptional finds in the African context, the existing veterinary literature can help us to establish which diseases affect donkeys in Africa today, the 
Fig. 2 The current and historical distributions of the three subspecies of the African wild ass (Equus africanus) compared to that of the three extant species of zebra (E. grevyi, E. quagga, E. zebra) (after Moehlman 2002; Kimura et al. 2013):

A E. africanus atlanticus,

B E. africanus africanus,

C E. africanus somaliensis and D likely mid-Holocene distribution of E. africanus in the Sahara, left open-ended at top right to allow for the species' presence in Southwest Asia

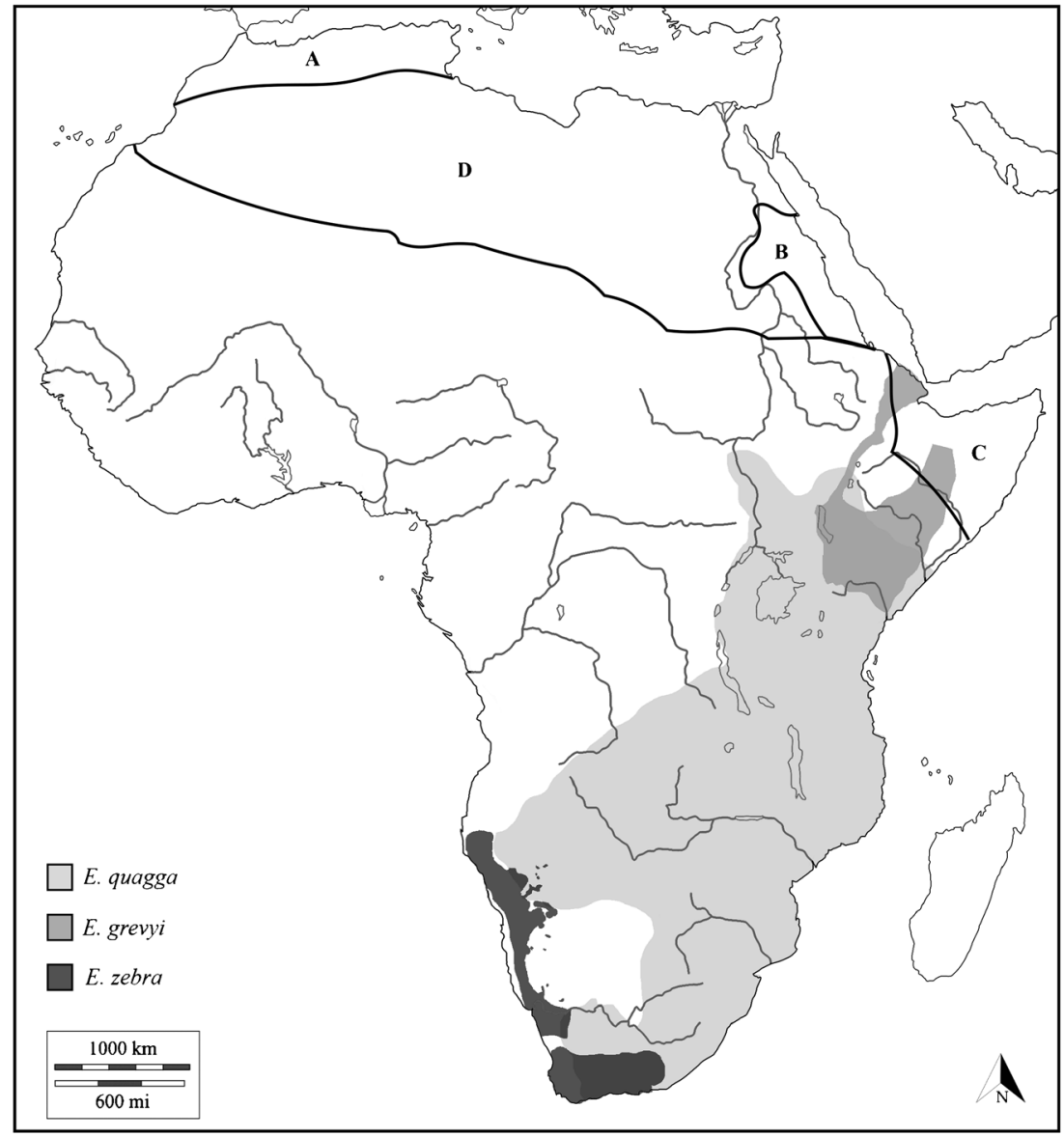

conditions under which they occur and the effects that they produce. If one species or population (i.e., donkeys) exhibits more virulent forms of a given disease than another (e.g., zebras), then the former likely received it more recently, while if African populations show some degree of tolerance to a particular pathogen, then not only is this likely to have taken some time evolve, but also the disease itself probably once posed a more serious threat within Africa itself (cf. Gifford-Gonzalez 2000).

However, while donkeys are of considerable - and in many areas growing-importance to people, the diseases from which they suffer remain woefully understudied (Pearson et al. 1999, p. 194). This reflects two things. First, since donkeys are primarily used to transport people and goods rather than reared for food, export (alive or dead) or being kept as companions, they are perceived to be of lower economic value and thus attract less veterinary attention than other domestic animals (Stringer et al. 2015, p. 6). Second, the individuals (often women) and communities for whom donkeys are particularly important are themselves typically among the poorer, more marginal sections of the population (Jacobs 2001; Geiger and Hovorka 2015). Once again, this has reduced the amount of veterinary research directed at them, even if they are increasingly understood to offer important tools of empowerment for those same groups (Starkey 1995).

Compounding these difficulties, all too often statements about the effects of major infectious diseases on donkeys are extrapolated from what is known about horses (Segwagwe et al. 2000, p. 179), despite the fact that the two species show many differences (Burden and Thiemann 2015) and exhibit different symptoms that may vary considerably in their severity. As a result, donkeys remain "especially neglected when it comes to disease investigation, control and prevention" (Getachew et al. 2014, p. 236) and overviews of disease in them are few (but see Segwagwe et al. 2000; Getachew et al. 2014; Getachew et al. 2016). What follows may therefore easily underestimate the impacts 
of the infections that I discuss and the number of significant disease threats to which donkeys are exposed in Africa.

\section{Trypanosomiasis}

Sleeping sickness is one of the best-known insect-borne diseases in Africa, affecting more than 30 mammal taxa, including wild animals, domestic livestock and people. The causal agents are parasitic protozoa of the genus Trypanosoma that are principally spread by various species of tsetse fly (Glossina spp.), although blood-eating (haematophagous) flies and Trictonid bugs can also act as vectors of some species (Uilenberg 1998). Having been ingested when the vector insect bites and feeds on the blood of a mammalian host, the trypanosome goes through a further part of its life cycle and then moves into the fly's salivary glands ready to begin another cycle of infection.

Equines (i.e., horses and mules, as well as donkeys) are often less of a preferred target for tsetse flies than cattle (Radostits et al. 2007), but it is widely acknowledged that horses are severely affected by the disease (Namangala and Odongo 2014). What is less commonly appreciated is that donkeys are far from resistant to it (Gifford-Gonzalez 1998, p. 192) and may suffer high rates of infection accompanied by extensive morbidity and mortality. Indeed, in some parts of Africa (for example, southwestern Burkina Faso) they exhibit higher frequencies of infection than cattle (Sow et al. 2014). The omission of donkeys from Namangala and Odongo's (2014, Table 10.1) list of animals affected by nagana (animal — as opposed to human - trypanosomiasis) is therefore bizarre or, rather, yet another manifestation of the neglect to which African donkeys and their diseases are exposed.

At least three species of Trypanosoma have been identified as causing infection in African donkeys: T. congolense, T. vivax and T. brucei. In addition, donkeys are also susceptible to two other trypanosomal conditions not discussed here, surra (caused by $T$. evansi) and dourine (caused by T. equiperdum), neither of which involves tsetse flies. Glossina spp., the principal vectors for the other three trypanosomes and the only one reported for Trypanosoma brucei (Namangala and Odongo 2014 , p. 233), currently range between $14^{\circ} \mathrm{N}$ and $29^{\circ} \mathrm{S}$ of the Equator. They need shady bush environments in which to rest and reproduce and find their most common animal hosts among nonmigratory mammals living in such conditions. Broadly speaking, this limits them to areas where mean annual rainfall is greater than 500 $700 \mathrm{~mm}$ (Nash 1969), with infection rates peaking in the wet season when circumstances are most favourable for their reproduction and survival.

Both the distribution and intensity of rainfall have, of course, changed over the course of the Holocene, most obviously as aridification of the Sahara led rainfall belts to contract southward toward the Equator, producing significant effects on where people were able to keep cattle (Jousse 2006). On a more localised level, fluctuations in tsetse infestation have been inferred from variation in the presence and absence of cattle at archaeological sites in South Africa's Kruger Park over the past 1700 years (Plug 1989) and from stable isotope analysis of herbivore teeth at Gogo Falls, Lake Victoria, Kenya (Chritz et al. 2015). In broad terms, however, over the period with which we are concerned here tsetse flies and trypanosomiasis are likely to have been endemic to almost all of Africa south of the Equator and north of the Namib/Kalahari Deserts and the Grassland Biome of southern Africa (Fig. 3).

Several studies exist regarding the impact on donkeys of the various primarily tsetse-borne infections. In southern Ethiopia, for instance, Kanchula and Abebe (1997) documented a trypanosomiasis infection rate of $21 \%$, equal to that found in the same area among horses, and with Trypanosoma vivax the most common agent. Later work by Assefa and Abebe (2001) indicated, however, that $T$. congolense was the most prevalent source of infection, consistent with studies in Kenya (Nudungu et al. 1998) and The Gambia (Mattioli et al. 1994). The savanna-dwelling tsetse species $G$. morsitans, G. pallidipes and G. submorsitans were the predominant vectors involved. Conversely, a second Gambian study documented an infection rate of $78 \%$ for T. vivax, one of $36 \%$ for T. congolense and one of 28 $\%$ for $T$. brucei, with half of all the donkeys examined being infected with two, and sometimes as many as five, different parasite taxa (Pinchbeck et al. 2008). The significance of this study lies also in its employment of species-specific PCR after Whole Genome Amplification, which demonstrated a more than fourfold increase in levels of infection compared to conventional microscope-based detection methods (83\% compared to $18 \%$ ). While infection rates may vary considerably between regions (e.g., Bedada and Dagnachew 2012), the moral of this research is clearly that previous investigations indicating a lower prevalence of trypanosomiasis in donkeys relative to horses, or other livestock, need to be 


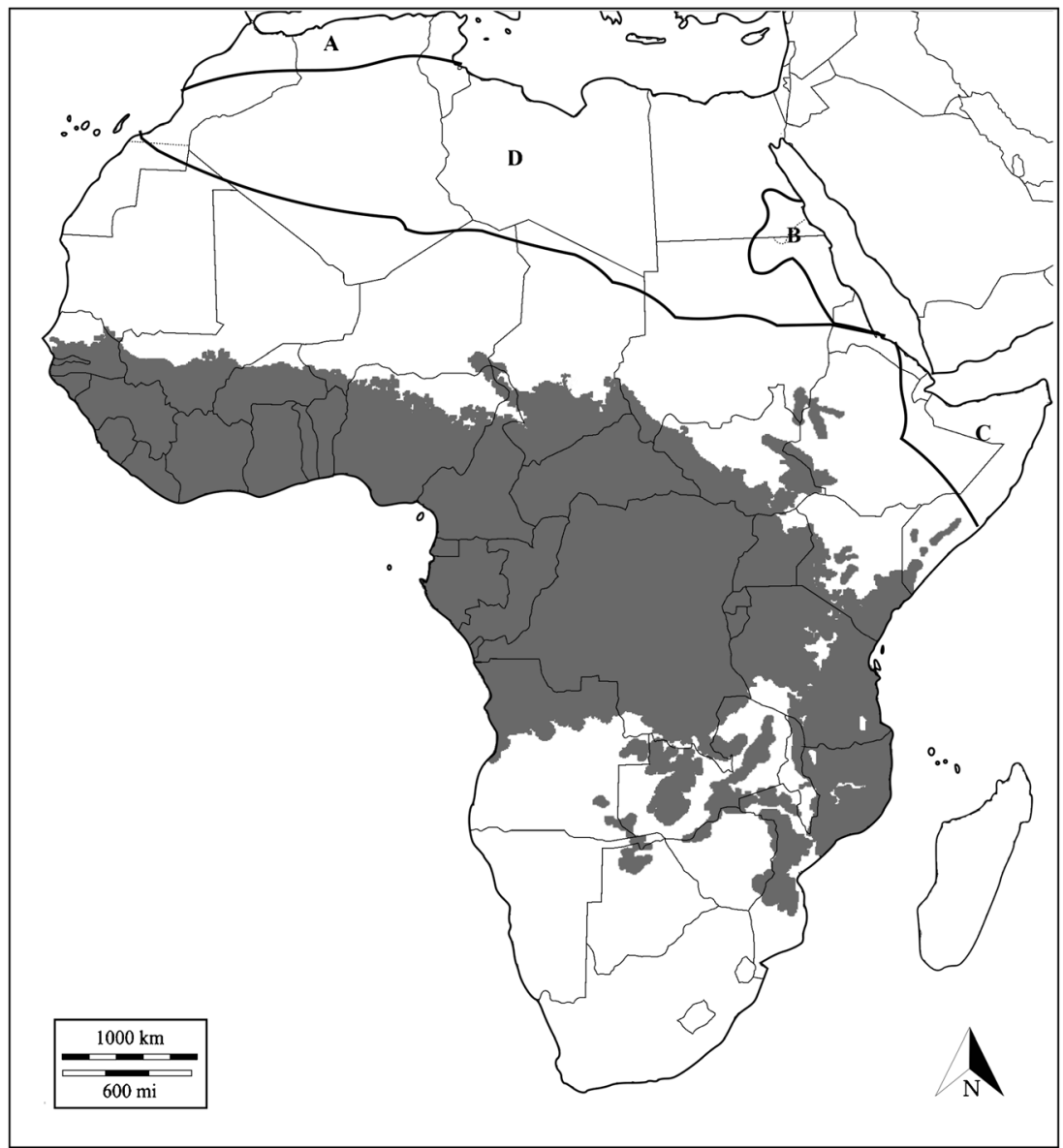

Fig. 3 The current distribution within Africa of Trypanosoma brucei, Trypanosoma congolense and Trypanosoma vivax (after Bowman et al. 2002, Fig. 1.52; Symula et al. 2012, Fig. 1; Garcia et al. 2014, Fig. 1) and the historical distribution of the African wild ass (Equus africanus) (after Kimura et al. 2013):

reassessed (cf. Dhollander et al. 2006). Such reassessments ought also to control for seasonal variation in tsetse activity, tethering practices and level of chemoprophylactic use (Mesele and Leta 2010).

Existing data nevertheless affirm that donkeys seem highly susceptible to Trypanosoma spp. and that infection can cause "severe clinical disease" (Getachew et al. 2016, p. S107), with greatly shortened life expectancies in areas of high tsetse/trypanosomiasis infestation (Sow et al. 2014). Among other studies, Burden et al. (2010) note that trypanosomiasis is "amongst the greatest constraints of donkey keeping" in Kenya's Lamu Archipelago, while in The Gambia, Faye et al. (2001, p. 102) observe, with respect to horses and donkeys, that "equine mortality rates exceed the foaling rates," a situation that is clearly unsustainable in the absence of continued
A E. africanus atlanticus, B E. africanus africanus, C E. africanus somaliensis and D likely mid-Holocene distribution of E. africanus in the Sahara, left open-ended at top right to allow for the species' presence in Southwest Asia

importation of new stock from areas that have much less, or even no, disease presence. But although all three of the trypanosomes discussed thus far are significant causes of anaemia, unthriftiness and reduced capacity for work (Burden et al. 2010), they are not equally dangerous. Thus, Assefa and Abebe (2001) suggest that T. vivax produces a milder infection than $T$. congolense, as is generally true for East African livestock as a whole (Namangala and Odongo 2014).

T. brucei, on the other hand, appears to strike equally at both horses and donkeys, producing a severe infection that is often fatal (Connor 1994). Indeed, in The Gambia, T. brucei infection is more common in donkeys than in horses (Pinchbeck et al. 2008) and both this study and others (e.g., Dhollander et al. 2006; Mesele and Leta 2010) raise the possibility that the relatively 
low rates of infection attributed to T. brucei may well underestimate its impact on sub-Saharan donkey populations because of the increased pathogenicity, and thus the higher mortality rates, associated with this particular trypanosome. Confirming this, experimental infection of donkeys with T. brucei has been observed to produce symptoms of dullness, weakness, fever and tachycardia, with death resulting in all cases within 8 to 10 weeks of initial infection (Ikede et al. 1977). More recently, Kingston et al. (2016) have documented infection of the central nervous system of donkeys by T. brucei in The Gambia, a condition that results in slowly deteriorating cerebral dysfunction and is usually fatal.

\section{Equine Piroplasmosis}

Equine piroplasmosis (or babesiosis) has previously been described as "the most serious infectious disease of horses in southern Africa” (Littlejohn and Walker 1979, p. 309), exceeding even the effects of African horse sickness, which I discuss below. Though best known from South Africa, it is far from restricted to that part of the continent and occurs in most tropical and subtropical regions of the world where suitable tick vectors are present (hence the lack of a distribution map in this paper). Two infectious agents are responsible for the condition, Theileria equi and Babesia caballi. While usually occurring separately, they may also simultaneously coinfect the same animal, although infection with T. equi is more common than infection with B. caballi (Wise et al. 2013). Both are piroplasmic protozoa of the same phylum (Apicomplexa) as Plasmodium, which causes malaria. However, T. equi exhibits several characteristics that distinguish it from other Babesia species, and RNA analysis suggests that it belongs to a phyletic group different from both Babesia and Theileria; its precise taxonomic classification thus remains unclear (Rothschild 2013).

The lifecycle of $T$. equi is still not completely understood, although, as is also the case for B. caballi, it involves three distinct stages. Like most other Babesia species, in mammals it only targets the red blood cells, with infection starting when the tick vector feeds on an animal. Proliferation of the parasite within the animal's erythrocytes then paves the way for the infection of any new, uninfected tick (Wise et al. 2013, p. 1336). A wide range of ticks may act as vectors for these parasites, including species of Dermacentor, Rhipicephalus and Hyalomma (Wise et al. 2013; Oduori et al. 2015), and the red-legged tick Rhipicephalus evertsi evertsi, in particular, is often observed on donkeys (De Waal and van Heerden 1994). T. equi can, however, also be transmitted transplacentally and may result in abortion, stillbirth or infection of a live foal (Wise et al. 2013, p. 1337). Horses at least can remain carriers of $B$. caballi for up to 4 years after initial infection (Holbrook et al. 1973). All three species of zebra have also been identified as carriers (Lampen et al. 2009; Hawkins et al. 2015), and T. equi is likely to have first evolved as an infection of zebras before affecting other equids (Bhoora et al. 2009).

Piroplasmosis has been reported in donkeys in Sudan, Ethiopia and Kenya but is likely to be much more widespread than this, as is the case with its occurrence in horses (Oduori et al. 2015). Clinically visible signs of infection, which are more evident when infection is caused by $T$. equi than by $B$. caballi, include loss of appetite, anaemia, oedema, reduced work efficiency, weight loss and abortion, with overwork putting donkeys at increased risk (Oduori et al. 2015, p. 684). Depression, marked thirst, constipation and spleen enlargement may also occur (Kumar et al. 2009). There are fewer donkey-focused studies of the disease than those investigating horses, however, with some suggesting that it is more often chronic than acute in nature (Laus et al. 2015). Indeed, Oduori et al. (2015, p. 685) note that in east-central Kenya, clinical signs could not be identified, "consistent with the nature of the disease in an endemic setting, where equids over time have developed protective immunity."

Nevertheless, equine piroplasmosis has elsewhere been described as one of the most important tick borne diseases to afflict donkeys (Kumar et al. 2009) and in northeastern South Africa, where donkeys were introduced from the mid-1800s, it caused "a great mortality" at the start of the twentieth century, comparable to its effects in horses (Bowhill 1905, p. 7). Experimental infection of donkeys with $T$. (formerly $B$.) equi confirms its pathogenicity (Singh et al. 1980; Kumar et al. 2003), while Segwagwe et al. (2000, p. 181) observe that in Botswana "donkeys are known to be equally as susceptible as horses to $B$. equi and B. caballi." It thus seems likely that when donkeys with no previous history of exposure (and resistance) to equine piroplasmosis entered areas where they could be infected by ticks adapted to existing zebra reservoir populations they might well have suffered considerable losses. This possibility would be enhanced should it be possible to associate different clinical signs with the genetically 
Fig. 4 Map of Africa showing the likely historical distribution south of the Sahara of Culicoides imicola, the principal vector of African horse sickness (after Guichard et al. 2014, Fig. 2) and the historical distribution of the African wild ass (Equus africanus) (after Kimura et al. 2013): A E. africanus atlanticus, B E. africanus africanus, C E. africanus somaliensis and D likely mid-Holocene distribution of E. africanus in the Sahara, left open-ended at top right to allow for the species' presence in Southwest Asia

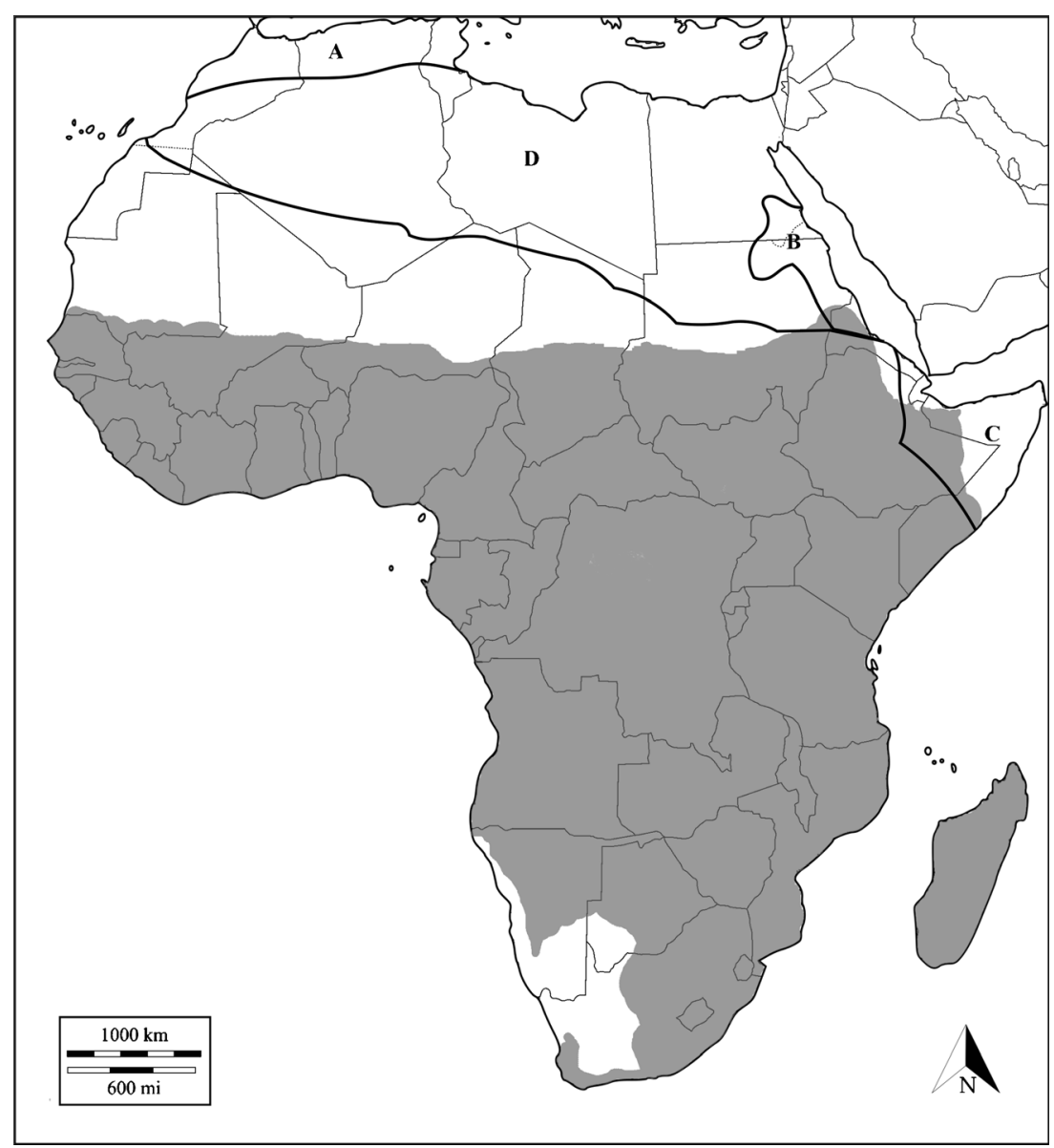

distinct groups of T. equi now beginning to be identified (cf. Lampen et al. 2009, p. 259).

\section{African Horse Sickness}

Caused by a virus of the same name that belongs to the family Reoviridae, African horse sickness is endemic to Sub-Saharan Africa (Fig. 4). It is principally spread by two midges of the genus Culicoides, mostly C. imicola, but in southern Africa also C. bolitinos (Mellor and Boorman 1995; Meiswinkel and Paweska 2003); other insect vectors, such as mosquitoes or ticks, may also play a role (Alexander et al. 1993; van Sittert et al. 2013). African horse sickness is endemic in eastern, central and much of southern Africa and the mortality rate in horses can reach as high as $95 \%$ (Coetzer and Guthrie 2004). There is some evidence that donkeys in general, and those in Africa in particular, mostly display subclinical signs if infected (e.g., Hamblin et al. 1998; Teshome et al. 2012), but those living in the
Middle East are much more susceptible, with mortality rates reaching $10 \%$ (Alexander 1948).

African horse sickness finds its primary natural host in zebras, though it is not impossible that other mammals also act as reservoirs (Wilson et al. 2009, p. 5). There is neither archaeological nor palaeontological evidence for the presence of any of the extant species of zebra within the Sahara or to its north during the Holocene (MacDonald and MacDonald 2000, p. 139; Churcher 2014; Faith 2014). Nor is there likely to have been significant distributional overlap between any zebra species and the African wild ass (Fig. 2). Epidemiologically naïve populations of donkeys encountering African horse sickness for the first time as they moved south might thus have reacted like modern animals in the Middle East on first exposure to the virus, even if they subsequently evolved the degree of immunity that some studies suggest and that their presence in parts of East Africa for some 3000 years would support. Unlike the other two diseases that I have discussed, African horse sickness is thus unlikely to have been a constraint 
on keeping donkeys in areas where the disease itself is endemic.

\section{Discussion and Conclusion}

All three of the diseases I have discussed pose health threats to donkeys, most especially in the cases of equine piroplasmosis and of trypanosomiasis caused by infection with T. brucei. Nevertheless, at least some donkey populations - for example those examined in Kenya by Oduori et al. (2015) - show a degree of resistance to the latter condition, and African donkeys in general appear to suffer much less from African horse sickness than those living elsewhere. The corollary of these propositions is, however, that such immunity must have taken time to evolve and that on first exposure donkey mortality and morbidity rates will have been much higher. This is to be expected given the restriction of the donkey's ancestor, the African wild ass, to arid and semiarid regions of North and Northeast Africa in the Pleistocene and early Holocene. These regions experienced rainfall that was too low to support populations of Glossina spp., and animals living there cannot therefore have been exposed to trypanosomiasis. That E. africanus only has thin stripes on its lower legs is fully consistent with this since the distribution of zebras shows an almost perfect correlation with that of biting flies, especially Glossina spp., and the width of zebra stripes appears to deter tsetse and tabanid flies from biting them (Caro et al. 2014; Fig. 2).

The absence of zebras from the Sahara, Sudan and most of the Horn of Africa also makes it likely that donkeys living in these areas underwent little, if any, exposure to two other major diseases, both of which find their primary hosts in zebra populations-equine piroplasmosis and African horse sickness. Even the historical distribution of Grévy's zebra, the more dryland adapted of the two taxa present in East Africa, shows virtually no overlap with that of the wild ass (Fig. 3). Such overlap as may have existed (in western Djibouti, the lower Awash Valley and parts of the Somali Region of Ethiopia) would, in any case, only have been with the Somali subspecies of the wild ass (E. africanus somaliensis), which genetic analyses demonstrate is not ancestral to the domestic donkey and which last shared a common ancestor with donkeys and Nubian wild asses over 100,000 years ago (Kimura et al. 2011).

The archaeozoological record for donkeys in the Pastoral Neolithic of East Africa remains sparse, with relevant observations coming from a mere handful of sites. Nevertheless, it shows that donkeys were present in the region in the first millennium $\mathrm{BC}$, in both the Loita Plains of southwestern Kenya and on the southern side of Lake Eyasi in northern Tanzania. The latter area marks the most southerly known extension of Pastoral Neolithic settlement and it is thus to it, or areas nearby, that we need to look for the origin of those groups that introduced cattle, sheep, ancestral forms of the Khoe language family and, perhaps, pottery, to Africa south of the Zambezi in the last few centuries BC (based on dates from Leopard Cave, Namibia, Spoegrivier, South Africa and Toteng, Botswana; Sealy and Yates 1994; Robbins et al. 2008; Pleurdeau et al. 2012). Gifford-Gonzalez $(2000,2016)$ has demonstrated that a number of serious infectious diseases, including trypanosomiasis, probably handicapped the southward spread of domestic livestock, especially cattle, into East Africa and between East Africa and southern Africa. The recent elegant analysis of Chritz et al. (2015) reconstructing more open grassland conditions around Gogo Falls on the eastern side of Lake Victoria in the first few centuries AD does not gainsay this since neither its location (too far north) nor date (too recent) are directly relevant to the expansion of livestock to southern Africa. It does, however, highlight the direction that palaeoenvironmental research must take in order to establish where a diseasefree corridor lay, however ephemeral it may have been.

But while caprines and cattle took advantage of that corridor to reach southern Africa, donkeys - according to the evidence of early historical accounts and archaeology - did not. The precise reasons for this are likely to have been complex-perhaps in the first instance even specific to the (small?) groups from which those introducing herding to the south in the last couple of centuries BC derived-but the donkey's failure to spread into southern or, indeed, south-central Africa at any time before European contact suggests the operation of an ongoing and long-standing cause. Disease is, I submit, an obvious possibility, and I have shown that not only are donkeys are susceptible to trypanosomiasis but that they are particularly at risk to the form of the disease caused by $T$. brucei, which is frequently fatal and at least as dangerous to them as it is to horses. Interestingly, T. brucei is less serious for domestic 
ruminants than T. vivax and T. congolense (Namangala and Odongo 2014, p. 244), which raises the possibility that sheep, goats and cattle might have been able to pass through areas infected with it, while donkeys were kept at bay. Equine piroplasmosis is also likely to have posed significant dangers, though here the veterinary evidence is arguably more mixed, with the risk varying depending on the specific strain of the protozoa and virus involved. African horse sickness, on the other hand, seems to have been a challenge that was easier to meet and, at least in East Africa, donkeys today display primarily subclinical signs when infected by it.

As with the constraints imposed by disease on the southward spread of other livestock (Gifford-Gonzalez 2016), my hypothesis is easily refutable by future archaeozoological research, but even if donkeys should be identified in archaeological faunas significantly south of the Lake Eyasi area the question must remain why they did not continue south. Had they done so, they would presumably have found most of Namibia and Botswana and large parts of South Africa and Lesotho highly inviting, just like their twentieth- and twenty-firstcentury successors. Moreover, given their significance for today's East African pastoralists in enhancing flexible mobility in dryland areas, particularly in transporting water, firewood and other resources (Marshall and Weissbrod 2009), they would presumably have made life considerably easier for Stone Age herders in the semiarid regions of the western half of southern Africa. In their absence, at least some of those herders used cattle to move their mat houses and personal possessions (Smith 1992, pp. 200-201), animals that are slower and energetically less efficient, must rest to ruminate and have significantly higher water and nutritional needs (Marshall 2007). Perhaps learned from Khoekhoe cattle-keepers, southern Nguni groups in South Africa also employed cattle as pack animals, but the practice did not reach beyond them (Wilson 1982, pp. 108-109). Elsewhere in southern and south-central Africa, therefore all goods had to be moved on people's heads or by canoe. Given that donkeys can carry loads of 80-100 kg for 24-30 km a day (Raepsaet 2008, Table 23, p. 4) compared to the 25-35 kg recorded for precolonial African porters (Alpers 1977, p. 222), agropastoralist societies must have been significantly hampered by the absence of pack animals, for example in moving staples such as basic foodstuffs over long distance given that people would have had to consume some of what they were moving to achieve this (cf. Drennan 1984; for a direct, text-aided comparison, donkeys in the Near Eastern Bronze Age carried $250 \%$ as much as human porters; Dercksen 1996).

To sum up, the donkey's absence from southern Africa in precolonial times is established by its total omission from early (fifteenth- to nineteenth-century) European accounts of the region and its concomitant lack of identification in pre-nineteenth century archaeological faunas. This absence surely implies the presence of a deterrent or barrier between it and East Africa. That barrier was, I argue, not merely an asinine aversion to more wooded or wetter savanna environments per se, but rather to the diseases that those environments harboured. To take this proposition further, several additional lines of evidence can be investigated.

First, the many specimens currently attributable only to Equus sp. from sites in East Africa mightwhere collagen is preserved-be investigated using new palaeoproteomic (ZooMS) techniques (e.g., Welker et al. 2015) to determine whether additional donkeys lurk unidentified in Pastoral Neolithic or other faunal assemblages; they and existing specimens would also benefit from direct dating using the AMS radiocarbon technique to confirm their precise age. Along with renewed archaeozoological examinations, the same techniques could also be deployed as part of efforts to exclude conclusively the possibility that donkeys lie "hidden" and unidentified in southern African faunas; Geduld (Smith and Jacobson 1995) and Bosutswe (Denbow et al. 2008) might, for example, be promising in this respect (Table 2). Second, the genomes of donkeys, particularly those thought to represent populations long native to East Africa, could be investigated to ascertain whether they show evidence of having evolved resistance to the diseases I have discussed. Third, improved veterinary understanding of disease in the donkey-rather than mere extrapolation from single sources or studies focused on horses alone-would better establish the precise impact on E. asinus of trypanosomiasis, equine piroplasmosis and African horse sickness, as well as the effects (and origins, in Africa or beyond) of other diseases not considered here, such as equine infectious anaemia that are also spread by insect vectors (Caro et al. 2014, Supplementary Table 1). Finally, as with cattle (Gifford-Gonzalez 2000), it would be worth establishing to what degree African donkey keepers practise forms of livestock management or environmental modification that may protect their 
animals from infection. By pursuing all these paths, we shall find ourselves looking at-rather than overlooking - the role of infectious disease in the spread within Africa of its one domesticated native ungulate.

Acknowledgments I am grateful to Patrick Roberts, Fiona Marshall and an anonymous reviewer for their comments and to Sam Lunn-Rockliffe for producing the maps that accompany this paper. While I have cited the results of studies involving the deliberate infection of donkeys, I do not approve of the use of animals in such work.

\section{Compliance with Ethical Standards}

Conflicts of Interest The author declares that he has no conflicts of interest.

Open Access This article is distributed under the terms of the Creative Commons Attribution 4.0 International License (http:// creativecommons.org/licenses/by/4.0/), which permits unrestricted use, distribution, and reproduction in any medium, provided you give appropriate credit to the original author(s) and the source, provide a link to the Creative Commons license, and indicate if changes were made.

\section{References}

Alexander, R. A. (1948). The 1944 epizootic of horsesickness in the Middle East. Onderstepoort Journal of Veterinary Science and Animal Industry, 23, 77-82.

Alexander, K. A., Kat, P. W., House, J., House, C., O’Brien, S. J., Laurenson, M. K., McNutt, J. W., \& Osburn, B. J. (1993). African horse sickness and African carnivores. Veterinary Microbiology, 47, 133-140.

Alpers, E. A. (1977). The East African slave trade. In Z. A. Konczacki \& J. M. Konczacki (Eds.), An economic history of tropical Africa, vol. 1, the pre-colonial period (pp. 206215). Abingdon: Frank Cass and Co.

Assefa, E., \& Abebe, G. (2001). Drug-resistant Trypanosoma congolense in naturally infected donkeys in north Omo Zone, southern Ethiopia. Veterinary Parasitology, 99, 261271.

Badenhorst, S., Plug, I., Pelser, A. J., \& van Vollenhoven, A. C. (2002). Faunal analysis from Steinaecker's Horse, the northernmost British military outpost in the Kruger National Park during the South African War. Annals of the Transvaal Museum, 39, 57-63.

Bedada, H., \& Dagnachew, S. (2012). Study on the prevalence of donkey trypanosomiasis in Awi zone northwest Ethiopia. Ethiopian Veterinary Journal, 16(2), 65-76.

Beja-Pereira, A., England, P. R., Ferrand, N., Jordan, S., Bakhiet, A. O., Abdalla, M. A., Mashkour, M., Jordana, J., Taberlet, P., \& Luikart, G. (2004). African origins of the domestic donkey. Science, 304, 1781.
Bhoora, R., Franssen, L., Oosthuizen, M., Guthrie, A. J., Zweygarth, E., Penzhorn, B. L., Jongejan, F., \& Collins, N. E. (2009). Sequence heterogeneity in the $18 S$ rRNA gene within Theileria equi and Babesia caballi from horses in South Africa. Veterinary Parasitology, 159, 112-120.

Blench, R. M. (2000). A history of donkeys, wild asses and mules in Africa. In R. M. Blench \& K. C. MacDonald (Eds.), The origins and development of African livestock: Archaeology, genetics, linguistics and ethnography (pp. 339-354). London: UCL Press.

Boessneck, J., \& von den Driesch, A. (1998). Tierreste aus der vorgeschichtlichen siedlung von El-Omari bei Heluan/ UnterÄgypten. In F. Debono \& B. Montensen (Eds.), El Omari (pp. 99-101). Mainz: Philip von Zabern.

Boessneck, J., von den Driesch, A., \& Ziegler, R. (1989). Die Tierreste von Maadi und Wadi Digla. In I. Rizkana, \& J. Seeher (Eds.), Maadi III (pp. 87-128). Mainz: Philip von Zabern.

Boessneck, J., von den Driesch, A., \& Eissa, A. (1992). Eine Eselsbestattung der 1. Dynastie in Abusir. Mitteilungen des Deutschen Archäologischen Instituts Abteilung Kairo, 48, 110.

Boettger, C. (1958). Die Haustiere Afrikas. Jena: G. Fischer.

Bowhill, T. (1905). Equine piroplasmosis to "biliary fever." The Journal of Hygiene, 5(1), 7-17.

Bowman, D. D., Hendrix, C. M., Lindsay, D. S., \& Barr, S. C. (2002). Feline clinical parasitology. Ames: Iowa State University Press.

Burchell, W. J. (1953). Travels in the interior of southern Africa. London: The Batchworth Press.

Burden, F., \& Thiemann, A. (2015). Donkeys are different. Journal of Equine Veterinary Science, 35, 376-382.

Burden, F., Getachew, M., \& Trawford, A. F. (2010). Epidemiology and control of donkey trypanosomiasis and their vectors in the Lamu Islands. http://research. thedonkeysanctuary.org.uk/project/463. Website Accessed 14 Apr 2016.

Burleigh, R., Clutton-Brock, J., \& Gowlett, J. (1991). Early domestic equids in Egypt and Western Asia: An additional note. In R. H. Meadow \& H.-P. Uerpmann (Eds.), Equids of the ancient world, volume 2 (pp. 9-11). Wiesbaden: Reichert.

Cain, C. R. (1999). Results from zooarchaeological analysis at Axum, Ethiopia. Archaeozoologia, 10, 27-45.

Caro, T., Izzo, A., Reiner, R. C., Walker, H., \& Stankowich, T. (2014). The function of zebra stripes. Nature Communications, doi: 10.1038/ncomms4535.

Chaix, L. (1993). The archaeozoology of Kerma (Sudan). In W. V. Davies \& R. Walker (Eds.), Biological anthropology and the study of Ancient Egypt (pp. 175-185). London: British Museum Press.

Chaix, L. (2008). Animal exploitation during Napatan and Meroitic times in the Sudan. In W. Goldewski \& A. Łajtar (Eds.), Between the Cataracts: Proceedings of the 11th Conference for Nubian Studies, Warsaw University, 27 August-2 September 2006 (pp. 519-525). Warsaw: Warsaw University Press.

Chaix, L. (2013). The fauna from the UNO.BU excavations at Bieta Giyorgis (Aksum) in Tigray, Northern Ethiopia: Campaigns 1995-2003; Pre-Aksumite, 700-400 BC to Late Aksumite, AD 800-1200. Journal of African Archaeology, 11, 211-241. 
Chritz, K. L., Marshall, F. B., Zagal, M. E., Kirera, F., \& Cerling, T. E. (2015). Environments and trypanosomiasis risks for early herders in the late Holocene of the Lake Victoria basin, Kenya. Proceedings of the National Academy of Sciences (USA), 112, 3674-3679.

Churcher, C. S. (2014). A vacant niche? The curious distribution of African Perissodactyla. Transactions of the Royal Society of South Africa, 69, 1-8.

Closse, K. (1998). Les ânes dans 1'Egypte ancienne. Anthropozoologica, 27, 27-29.

Clutton-Brock, J. (2000). Cattle, sheep, and goats south of the Sahara: An archaeozoological perspective. In R. M. Blench \& K. C. MacDonald (Eds.), The origins and development of African livestock: Archaeology, genetics, linguistics and ethnography (pp. 30-37). London: UCL Press.

Coetzer, J. A. W., \& Guthrie, A. J. (2004). African horse sickness. In J. A. W. Coetzer \& R. C. Tustin (Eds.), Infectious diseases of livestock (pp. 1231-1246). Cape Town: Oxford University Press.

Connor, R. J. (1994). African animal trypanosomiases. In J. A. W. Coetzer, G. R. Thomson, \& R. C. Tustin (Eds.), Infectious diseases of livestock with special reference to southern Africa (pp. 167-205). Oxford: Oxford University Press.

D’Andrea, A. C., Richards, M. P., Pavlish, L. A., Wood, S., Manzo, A., \& Wolde-Kiros, H. S. (2011). Stable isotopic analysis of human and animal diets from two pre-Aksumite/ proto-Aksumite archaeological sites in northern Ethiopia. Journal of Archaeological Science, 38, 367-374.

De Waal, D. T., \& van Heerden, J. (1994). Equine babesiosis. In J. A. W. Coetzer, G. R. Thomson, \& R. C. Tustin (Eds.), Infectious diseases of livestock with special reference to southern Africa (pp. 293-304). Oxford: Oxford University Press.

Deacon, H. J., Deacon, J., Brooker, M., \& Wilson, M. L. (1978). The evidence for herding at Boomplaas Cave in the southern Cape, South Africa. South African Archaeological Bulletin, $33,39-65$.

Dębowska-Ludwin, J. (2012). Traces of early Egyptian burial rituals in Proto- and Early Dynastic graves from Tell elFarkha. Studies in Ancient Art and Civilization, 16, 39-48.

Denbow, J. R., Smith, J., Ndobochani, N. M., Atwood, K., \& Miller, D. (2008). Archaeological excavations at Bosutswe, Botswana: Cultural chronology, paleo-ecology and economy. Journal of Archaeological Science, 35, 459-480.

Dent, A. (1972). Donkey: The story of the ass from east to west. London: George Harrap.

Dercksen, J. G. (1996). The Old Assyrian copper trade. Istanbul: Nederlands Historisch-Archaeologisch Institut.

Dhollander, S., Jallow, A., Mbodge, K., Kora, S., Sanneh, M., Gaye, M., Bos, J., Leak, S., Berkvens, D., \& Geerts, S. (2006). Equine trypanosomiasis in the Central River Division of The Gambia: A study of veterinary gate-clinic consultation records. Preventive Veterinary Medicine, 75, $152-162$.

di Lernia, S. (2013). The emergence and spread of herding in northern Africa: A critical reappraisal. In P. J. Mitchell \& P. J. Lane (Eds.), The Oxford handbook of African archaeology (pp. 527-540). Oxford: Oxford University Press.

Dochniak, C. C. (1991). The Libyan Palette interpreted as depicting a combination pictorial year-name. Varia Aegyptiaca, 7, 108-114.
Drennan, R. D. (1984). Long-distance transport costs in preHispanic Mesoamerica. American Anthropologist, 86, 105112.

El-Menshawy, S. (2009). Uses of domesticated donkeys: Evidence from Old Kingdom tomb scenes. Abgadiyat, 4, 51-62.

Faith, J. T. (2014). Late Pleistocene and Holocene mammal extinctions on continental Africa. Earth Science Reviews, 128, 105-121.

Faye, D., Paulo, J. L., Pereira de Almeida, P. J. L., Goossens, B., Osaer, S., Ndao, M., Berkvens, D., Speybroeck, N., Nieberding, F., \& Geerts, S. (2001). Prevalence and incidence of trypanosomiasis in horses and donkeys in The Gambia. Veterinary Parasitology, 101, 101-114.

Flores, D. V. (2003). Funerary sacrifice of animals in the Egyptian Predynastic period. Oxford: Archaeopress.

Förster, F. (2013). Beyond Dakhla: The Abu Ballas Trail in the Libyan Desert (SW Egypt). Africa Praehistorica, 27, 297338.

Garcia, H. A., Rodrigues, A. C., Rodrigues, C. M. F., Bengaly, Z., Minervino, A. H. H., Riet-Correa, F., Macahdo, R. Z., Paiva, F., Batista, J. S., Neves, L., Hamilton, P. B., \& Teixeira, M. M. G. (2014). Microsatellite analysis supports clonal propagation and reduced divergence of Trypanosoma vivax from asymptomatic to fatally infected livestock in South America compared to West Africa. Parasites \& Vectors, 7, 210.

Gautier, A., \& Van Neer, W. (2006). Animal remains from Mahal Teglinos (Kassala, Sudan) and the arrival of pastoralism in the southern Atbai. Journal of African Archaeology, 4, 223234.

Gautier, A., \& Van Neer, W. (2009). Animal remains from predynastic sites in the Nagada region, Middle Egypt. Archaeofauna, 18, 27-50.

Geiger, M., \& Hovorka, A. J. (2015). Animal performativity: Exploring the lives of donkeys in Botswana. Environment and Planning D: Society and Space, 33, 1098-1117.

Getachew, M., Alemayehu, F., Chala, C., Amare, B., Kassa, D., Burden, F., Wernery, R., \& Wernery, U. (2014). A crosssectional sero-survey of some infectious diseases of working equids in central Ethiopia. Journal of Veterinary Medicine and Animal Health, 6, 231-238.

Getachew, M., Burden, F., \& Wernery, U. (2016). Common infectious diseases of working donkeys: Their epidemiological and zoonotic role. Journal of Equine Veterinary Science, 39, S106-S107.

Gifford-Gonzalez, D. P. (1998). Early pastoralists in East Africa: Ecological and social dimensions. Journal of Anthropological Archaeology, 17, 166-200.

Gifford-Gonzalez, D. P. (2000). Animal disease challenges to the emergence of pastoralism in Sub-Saharan Africa. African Archaeological Review, 17, 95-140.

Gifford-Gonzalez, D. P. (2016). "Animal disease challenges" fifteen years later: The hypothesis in light of new data. Quaternary International, doi 10.1016/j.quaint.2015.10.054.

Gifford-Gonzalez, D. P., \& Kimengich, J. (1984). Faunal evidence for early stock-keeping in the central Rift of Kenya: Preliminary findings. In L. Krzyzaniak \& M. Kobusiewiecz (Eds.), Origin and early development of food-producing cultures in north-east Africa (pp. 357-371). Poznán: Polish Academy of Sciences.

Grigson, C. (2006). Farming? Feasting? Herding? Large mammals from the Chalcolithic of Gilat. In T. E. Levy (Ed.), 
Archaeology, anthropology and cult: The sanctuary at Gilat, Israel (pp. 215-319). London: Equinox.

Guichard, S., Guis, H., Tran, A., Garros, C., Balenghien, T., \& Kriticos, D. J. (2014). Worldwide niche and future potential distribution of Culicoides imicola, a major vector of bluetongue and African horse sickness viruses. PloS One, 9(11), e112491.

Güldemann, T. (2008). A linguist's view: Khoe-Kwadi speakers as the earliest food-producers of southern Africa. Southern African Humanities, 20(1), 93-132.

Hamblin, C., Salt, J. S., Mellor, P. S., Graham, S. D., Smith, P. R., \& Wohlsein, P. (1998). Donkeys as reservoirs of African horse sickness virus. Archives of Virology Supplement, 14, 38-47.

Hanotte, O., Tawah, C. L., Bradley, D. G., Okomo, M., Verjee, Y., Ochieng, J., \& Regem, J. E. (2000). Geographic distribution and frequency of a taurine Bos taurus and an indicine Bos indicus gamma specific allele amongst sub-Saharan African cattle breeds. Molecular Ecology, 9, 387-396.

Hawkins, E., Kock, R., McKeever, D., Gakuya, F., Musyoki, C., Chege, S. M., Mutinda, M., Kariuki, E., Davidson, Z., Low, B., Skilton, R. A., Njahira, M. N., Wamalwa, M., \& Maina, E. (2015). Prevalence of Theileria equi and Babesia caballi as well as the identification of associated ticks in sympatric Grevy's zebras (Equus grevyi) and donkeys (Equus africanus asinus) in northern Kenya. Journal of Wildlife Diseases, 51, 137-147.

Henshilwood, C. S. (1996). A revised chronology for pastoralism in southernmost Africa: New evidence of sheep at c. $2000 \mathrm{bp}$ from Blombos Cave, South Africa. Antiquity, 70, 945-949.

Henshilwood, C. S. (2008). Holocene prehistory of the southern Cape, South Africa: Excavations at Blombos Cave and the Blombosfontein Nature Reserve. Oxford: Archaeopress.

Holbrook, A. A., Frerichs, W. M., \& Allen, P. C. (1973). Laboratory diagnosis of equine piroplasmosis. In J. T. Bryans \& H. Gerber (Eds.), Proceedings of the Third International Conference on Equine Infectious Diseases (pp. 467-475). Basel: Karger.

Hollmann, A. (1990). Sauergertierknochenfunde aus Elephantine in Oberägypten. Munich: Ludwig-Maximilians-Universitaet.

Houlihan, P. F. (2002). Animals in Egyptian art and hieroglyphs. In B. J. Collins (Ed.), History of the animal world in the ancient Near East (pp. 97-144). Leiden: Brill.

Huchet, J. B., Caillou, C., Lichtenberg, R., \& Dunand, F. (2013). The dog mummy, the ticks and the louse fly: Archaeological report of severe ectoparasitosis in Ancient Egypt. International Journal of Paleopathology, 3, 165-175.

Huffman, T. N. (1998). The antiquity of lobola. South African Archaeological Bulletin, 53, 57-62.

Huffman, T. N. (2007). Handbook to the Iron Age: The archaeology of pre-colonial farming societies in southern Africa. Scottsville: University of KwaZulu-Natal Press.

Ikede, B. O., Akpokodje, J. U., Hill, D. H., \& Ajdigaba, P. O. (1977). Clinical, haematological and pathological studies in donkeys experimentally infected with Trypanosoma brucei. Tropical Animal Health and Production, 9, 93-98.

IUCN (2015). Equus africanus. http://www.iucnredlist. org/details/7949/0. Website Accessed 18 Apr 2016.

Jacobs, N. J. (2001). The Great Bophuthatswana donkey massacre: Discourse on the ass and the politics of class. The American Historical Review, 106, 485-507.
Jesse, F., Kröpelin, S., Lange, M., Pöllath, N., \& Berke, H. (2004). On the periphery of Kerma - the Handessi Horizon in Wadi Hariq, northwestern Sudan. Journal of African Archaeology, 2, 123-164.

Johnstone, C. J. (2004). A biometric study of equids in the Roman world. $\mathrm{PhD}$ dissertation, University of York.

Jousse, H. (2006). What is the impact of Holocene climatic changes on human societies? Analysis of West African Neolithic populations' dietary customs. Quaternary International, 151, 63-73.

Kanchula, K., \& Abebe, G. (1997). Donkey's trypanosomiasis in north Omo Zone, southwest Ethiopia. Journal of the Ethiopian Veterinary Association, 1, 13-18.

Kebede, F. (2013). Ecology and community-based conservation of Grevy's zebra (Equus grevyi) and African wild ass (Equus africanus) in the Afar Region. University of Addis Ababa.

Kimura, B., Marshall, F. B., Chen, S., Rosenbom, S., Moehlman, P. D., Tuross, N., Sabin, R. C., Peters, J., Barich, B., Yohannes, H., Kebede, F., Reclai, R., Beja-Pereira, A., \& Mulligan, C. J. (2011). Ancient DNA from Nubian and Somali wild ass provides insights into donkey ancestry and domestication. Proceedings of the Royal Society B, 278, 50-57.

Kimura, B., Marshall, F. B., Beja-Pereira, A., \& Mulligan, C. (2013). Donkey domestication. African Archaeological Review, 30, 83-95.

Kingston, D., Rodgers, J., Sharpe, S., Berman, K., Morrison, L., Kennedy, P., Bradley, B., \& Sutton, D. M. G. (2016). Equine central nervous system trypanosomiasis in The Gambia is caused by genetically diverse populations of Trypanosoma brucei parasites. Journal of Equine Veterinary Science, 39, S100-S101.

Klein, R. G. (1978). A preliminary report on the larger mammals from the Boomplaas Stone Age cave site, Cango valley, Oudtshoorn District, South Africa. South African Archaeological Bulletin, 33, 66-75.

Klein, R. G., \& Cruz-Uribe, K. (1989). Faunal evidence for prehistoric herder-forager activities at Kasteelberg, western Cape Province, South Africa. South African Archaeological Bulletin, 44, 82-97.

Kolbe, P. (1731). The present state of the Cape of Good Hope. London: W. Innys.

Kumar, S., Gupta, A. K., Pal, Y., \& Dwivedi, S. K. (2003). In-vivo therapeutic efficacy trial with artemisinin derivative, buparvaquone and imidocarb dipropionate against Babesia equi infection in donkeys. Journal of Veterinary Medical Science, 65, 1171-1177.

Kumar, S., Kumar, R., \& Sugimoto, C. (2009). A perspective on Theileria equi infections in donkeys. Japanese Journal of Veterinary Research, 56, 171-180.

Kuper, R. (2006). After 5000 BC: The Libyan desert in transition. Comptes Rendus Palevol, 5, 409-419.

Lampen, F., Bhoora, R., Collins, N. E., \& Penzhorn, B. L. (2009). Putative clinical piroplasmosis in a Burchell's zebra (Equus quagga burchelli). Journal of the South African Veterinary Association, 80, 257-260.

Laus, F., Spatema, A., Faillace, V., Veronesi, F., Ravagnan, S., Beribé, F., Cerquetella, M., Meligrana, M., \& Tesei, B. (2015). Clinical investigation on Theileria equi and Babesia caballi infections in Italian donkeys. BMC Veterinary Research, 11, 100. 
Lima, V. S., Iniguez, A. M., Otsuki, K., Fernando Ferreira, L., Araújo, A., Vicente, A. C., \& Jansen, A. M. (2008). Chagas disease in ancient hunter-gatherer population, Brazil. Emerging Infectious Diseases, 14, 1001-1002.

Linseele, V., \& Pöllath, N. (2015). Local foods and traded goodsthe faunal remains from a Napatan outpost at Gala Abu Ahmed (Sudan, first millennium BC). African Archaeological Review, 32, 537-590.

Littlejohn, A., \& Walker, E. M. (1979). Some aspects of the epidemiology of equine babesiosis. Journal of the South African Veterinary Association, 50, 308-310.

Lombard, M. (2014). Human DNA and Stone Age archaeology. The Digging Stick, 31(2), 6-10.

Lombard, M., \& Parsons, I. (2015). Milk not meat: The role of milk amongst the Khoe peoples of southern Africa. Journal of African Archaeology, 13, 149-166.

MacDonald, K. C., \& MacDonald, R. H. (2000). The origins and development of domesticated animals in arid West Africa. In R. M. Blench \& K. C. MacDonald (Eds.), The origins and development of African livestock: Archaeology, origins, linguistics and ethnography (pp. 127-162). London: UCL Press.

Marshall, F. B. (1990). Cattle herds and caprine flocks. In P. T. Robertshaw (Ed.), Early pastoralists of south-western Kenya (pp. 205-260). Nairobi: British Institute in Eastern Africa.

Marshall, F. B. (2000). The origins and spread of domestic animals in East Africa. In R. M. Blench \& K. C. MacDonald (Eds.), The origins and development of African livestock: Archaeology, origins, linguistics and ethnography (pp. 191-221). London: UCL Press.

Marshall, F. B. (2007). African pastoral perspectives on domestication of the donkey. In T. Denham, J. Iriarte, \& L. Vrydaghs (Eds.), Rethinking agriculture: Archaeological and ethnoarchaeological perspectives (pp. 371-407). Walnut Creek: Left Coast Press.

Marshall, F. B., \& Weissbrod, L. (2009). The consequences of women's use of donkeys for pastoral flexibility: Maasai ethnoarchaeology. Documenta Archaeobiologicae, 7, 59-79.

Mattioli, R. C., Zinsstag, J., \& Pfister, K. (1994). Frequency of trypanosomiasis and gastrointestinal parasites in draught donkeys in The Gambia in relation to animal husbandry. Tropical Animal Health Production, 26, 102-108.

Meiswinkel, R., \& Paweska, J. T. (2003). Evidence for a new field Culicoides vector of African horse sickness in South Africa. Preventive Veterinary Medicine, 60, 243-253.

Mellor, P. S., \& Boorman, J. (1995). The transmission and geographical spread of African horse sickness and bluetongue viruses. Annals of Tropical Medicine and Parasitology, 89, $1-15$.

Mesele, F., \& Leta, S. (2010). Prevalence rate of tsetse transmitted donkey trypanosomiasis in Dale Wabera District, western Ethiopia. Global Veterinaria, 5, 180-183.

Mitchell, J. C. (1963). Marriage, matriliny and social structure among the Yao of southern Nyasaland. In K. Ishwaran \& J. Mogey (Eds.), Family and marriage (pp. 29-42). Leiden: E. J. Brill.

Mitchell, P. J. (2015). Did disease constrain the spread of domestic dogs (Canis familiaris) into Sub-Saharan Africa? Azania: Archaeological Research in Africa, 50, 92-135.

Moehlman, P. D. (Ed.). (2002). Status survey and conservation action plan: Equids, zebras, asses and horses. Gland: IUCN.
Mossop, E. E. (Ed.). (1935). The journal of Hendrik Jacob Wikar (1779) and the journals of Jacobus Coetsé Jansz (1760) and Willem van Reenen (1791). Cape Town: The Van Riebeeck Society.

Namangala, B., \& Odongo, S. (2014). Animal African trypanosomiasis in Sub-Saharan Africa and beyond African borders. In S. Magez \& M. Radwanska (Eds.), Trypanosomes and trypanosomiasis (pp. 239-260). Vienna: Springer.

Nash, T. A. M. (1969). Africa's bane. London: Collins.

Nudungu, J. M., Karanja, S. M., \& Githiori, J. B. (1998). Epidemiology of trypanosomiasis and other conditions of donkeys in Kenya. In Tercero Coloquio Internacional sobre Équidos de Trabajo, Mexico (DF) (pp. 44-150). Mexico City: Facultad de Medicina Veterinaria y Zootecnia, Universidad Nacional Autónoma de México.

O’Brien, S. J., Johnson, W., Driscoll, C., Pontius, J., PeconSlattery, J., \& Menotti-Raymond, M. (2008). State of cat genomics. Trends in Genetics, 24, 268-279.

Odner, K. (1972). Excavations at Narosura, a stone bowl site in the southern Kenya highlands. Azania, 7, 25-92.

Oduori, D. O., Onyango, S. C., Kimari, J. N., \& MacLeod, E. T. (2015). A field survey for the seroprevalence of Theileria equi and Babesia caballi in donkeys from Nuu Division, Kenya. Ticks and Tick-Borne Diseases, 6, 683-688.

Orton, J. D. (2015). The introduction of pastoralism to southernmost Africa: Thoughts on new contributions to an ongoing debate. Azania: Archaeological Research in Africa, 50, 250258.

Orton, J. D., Mitchell, P. J., Klein, R. G., Steele, T., \& Horsburgh, K. A. (2013). An early date for cattle from Namaqualand, South Africa: Implications for the origins of herding in southern Africa. Antiquity, 87, 108-120.

Pearson, R. A., Nengomasha, E., \& Krecek, R. (1999). The challenges in using donkeys for work in Africa. In P. Starkey \& P. G. Kalumbutho (Eds.), Meeting the challenges of animal traction (pp. 190-198). London: Animal Traction Network for Eastern and Southern Africa.

Pérez-Pardal, L., Royo, L. J., Beja-Pereira, A., Curik, I., Traoré, A., Fernández, I., Sölkner, J., Alonso, J., Álvarez, I., Bozzi, R., Chen, S., Ponce de León, F. A., \& Goyache, F. (2010). Yspecific microsatellites reveal an African subfamily in taurine (Bos taurus) cattle. Animal Genetics, 41, 232-241.

Peters, J. (1991). The faunal remains from Shaqadud. In A. E. Marks \& A. Mohammed-Ali (Eds.), The late prehistory of the eastern Sahel (pp. 197-235). Dallas: Southern Methodist University Press.

Pinchbeck, G. L., Morrison, L. J., Tait, A., Langford, J., Meehan, L., Jallow, S., Jallow, J., Jallow, A., \& Christley, R. M. (2008). Trypanosomiasis in The Gambia: Prevalence in working horses and donkeys detected by whole genome amplification and PCR, and evidence for interactions between trypanosome species. BMC Veterinary Research, 4, 7.

Pleurdeau, D., Imalwa, E., Détroit, F., Lesur, J., Veldman, A., Bahain, J.-J., \& Marais, E. (2012). "Of sheep and men": Earliest direct evidence of caprine domestication in southern Africa at Leopard Cave (Erongo, Namibia). PloS One, 7(7), e40340.

Plug, I. (1989). Aspects of life in the Kruger National Park during the Early Iron Age. South African Archaeological Society Goodwin Series, 6, 62-68. 
Plug, I. (1996). Domestic animals during the Early Iron Age in southern Africa. In G. Pwiti, \& R. Soper (Eds.), Aspects of African archaeology (pp. 515-520). Harare: University of Zimbabwe Press.

Plug, I., \& Badenhorst, S. (2001). The distribution of macromammals in southern Africa over the past 30, 000 years. Pretoria: Transvaal Museum.

Plug, I., \& Mitchell, P. J. (2008). Sehonghong: Hunter-gatherer utilization of animal resources in the highlands of Lesotho. Annals of the Transvaal Museum, 45, 31-53.

Plug, I., \& Voigt, E. A. (1985). Archaeozoological studies of Iron Age communities in southern Africa. Advances in World Archaeology, 4, 189-238.

Prendergast, M. E., \& Mutundu, K. K. (2009). Late Holocene zooarchaeology in East Africa: Ethnographic analogues and interpretive challenges. Documenta Archaeobiologicae, 5, 202-232.

Prendergast, M. E., Grillo, K. M., Mabulla, A. Z. P., \& Wang, H. (2014). Research note. New dates for Kansyore and Pastoral Neolithic ceramics in the Eyasi Basin, Tanzania. Journal of African Archaeology, 12, 89-98.

Radostits, O. M., Gay, C. C., Hinchcliff, W. K., \& Constable, P. D. (2007). Veterinary medicine. A textbook for the diseases of cattle, horses, sheep, pigs and goats. London: Springer.

Raepsaet, G. (2008). Land transport, part 2: Riding, harnesses, and vehicles. In J. P. Oleson (Ed.), The Oxford handbook of engineering and technology in the Classical World (pp. 580-605). Oxford: Oxford University Press.

Raven-Hart, R. (1971). Cape Good Hope 1652-1702/the first 50 years of Dutch colonisation as seen by callers. Cape Town: A. A. Balkema.

Richards, A. I. (1939). Land, labour and diet in Northern Rhodesia: An economic study of the Bemba tribe. Oxford: Oxford University Press.

Richardson, D. J., Guillén, S., Beckett, R., Kyle, W., Conlogue, G., \& Harper-Beckett, K. (2012). Archaeohelminthology of the Chiribaya shepherd Canis familiaris (700-1460 A.D.) from southern Peru. Comparative Parasitology, 79, 133137.

Robbins, L. H., Campbell, A. C., Murphy, M. L., Brook, G. A., Liang, F., Skaggs, S. A., Srivastava, P., Mabuse, A. A., \& Badenhorst, S. (2008). Recent archaeological research at Toteng, Botswana: Early domesticated livestock in the Kalahari. Journal of African Archaeology, 6, 131149.

Rosenbom, S., Costa, V., Al-Araimi, N., Kefena, E., AbdelMoneim, A. S., Abdalla, M. A., Bakhiet, A., \& BejaPereira, A. (2014). Genetic diversity of donkey populations from the putative centers of domestication. Animal Genetics, $46,30-36$.

Rossel, S., Marshall, F. B., Peters, J., Pilgram, T., Adams, M. D., \& O'Connor, D. (2008). Domestication of the donkey: Timing, processes, and indicators. Proceedings of the National Academy of Sciences (USA), 105, 511-519.

Rothschild, C. M. (2013). Equine piroplasmosis. Journal of Equine Veterinary Science, 33, 497-508.

Sadr, K. (2013). The archaeology of herding in southernmost Africa. In P. J. Mitchell \& P. J. Lane (Eds.), The Oxford handbook of African archaeology (pp. 645-656). Oxford: Oxford University Press.
Sandelowsky, B., van Rooyen, J. H., \& Vogel, J. C. (1979). Early evidence for herders in the Namib. South African Archaeological Bulletin, 34, 50-51.

Schapera, I., \& Farrington, B. (Eds.). (1933). The early Cape Hottentots. Cape Town: The Van Riebeeck Society.

Sealy, J. C., \& Yates, R. (1994). The chronology of the introduction of pastoralism to the Cape, South Africa. Antiquity, 68, 58-67.

Segwagwe, B. V. E., Aganga, A. A., \& Patrick, C. (2000). An investigation into the common diseases of donkeys (Equus asinus) in Botswana. In P. G. Kalumbutho, R. A. Pearson, \& T. E. Simalenga (Eds.), Empowering farmers with animal traction, proceedings of an ATNESA workshop, September 1999, South Africa (pp. 179-182). London: Animal Traction Network for Eastern and Southern Africa.

Shackelford, L., Marshall, F. B., \& Peters, J. (2013). Identifying donkey domestication through changes in cross-sectional geometry of long bones. Journal of Archaeological Science, 40, 4170-4179.

Singh, B., Banerjee, D. P., \& Gautam, O. P. (1980). Comparative efficiency of diminazene diaceturate and imidocarb dipropionate against Babesia equi infection in donkeys. Veterinary Parasitology, 7, 173-179.

Smith, A. (1975). Andrew Smith's journal of his expedition into the interior of South Africa 1834-1836. Cape Town: A. A. Balkema.

Smith, A. B. (1992). Pastoralism in Africa: Origins and development ecology. London: Hurst.

Smith, A. B. (2005). African herders: Emergence of pastoral traditions. Walnut Creek: AltaMira Press.

Smith, A. B., \& Jacobson, L. (1995). Excavations at Geduld and the appearance of early domestic stock in Namibia. South African Archaeological Bulletin, 50, 3-14.

Sow, A., Sidibé, I., Kalandi, M., Bathily, A., Ndiaye, N. P., Ouédrago, M., Mouiche, M. M. M., \& Sawadogo, G. J. (2014). Biochemical changes induced by natural infection of trypanosomiasis in Burkinabese local donkey breeds. Comparative Clinical Pathology, 23, 103-109.

Sparrman, A. (1975). A voyage to the Cape of Good Hope towards the Antarctic Polar Circle round the world and to the country of the Hottentots and the Caffres from the year 1772-1776 part 1. Cape Town: Van Riebeeck Society.

Sparrman, A. (1977). A voyage to the Cape of Good Hope towards the Antarctic Polar Circle round the world and to the country of the Hottentots and the Caffres from the year 1772-1776 part 2. Cape Town: Van Riebeeck Society.

Starkey, P. (Ed.). (1995). Animal power in South Africa: Empowering rural communities. Johannesburg: Development Bank of Southern Africa.

Starkey, P., \& Starkey, M. (2004). Regional and world trends in donkey populations. In P. Starkey \& D. Fielding (Eds.), Donkeys, people and development (pp. 10-21). Wageningen: ACP-EU Technical Centre for Agricultural and Rural Cooperation.

Stock, F., \& Gifford-Gonzalez, D. P. (2013). Genetics and African cattle domestication. African Archaeological Review, 30, 5172.

Stringer, A., Lunn, D. P., \& Reid, S. (2015). Science in brief: Report on the first Havemeyer workshop on infectious diseases in working equids, Addis Ababa, Ethiopia, November 2013. Equine Veterinary Journal, 47, 6-9. 
Swart, S. (2010). Riding high: Horses and human history in South Africa. Johannesburg: Wits University Press.

Symula, R. E., Beadell, J. S., Sistrom, M., Agbebakun, K., Balmer, O., Gibson, W., Aksoy, S., \& Caccone, A. (2012). Trypanosoma brucei gambiense group 1 is distinguished by a unique amino acid substitution in the $\mathrm{HpHb}$ receptor implicated in human serum resistance. PLoS Neglected Tropical Diseases, 6(7), e1728.

Teshome, M., Addis, M., \& Temesgen, W. (2012). Seroprevalence and risk factors of African horse sickness in mules and donkeys in selected sites of West Amhara region, Ethiopia. African Journal of Microbiology Research, 6, 4146-4151.

Thom, H. B. (1952). Journal of Jan van Riebeeck volume I 16521656. Cape Town: The Van Riebeeck Society.

Thom, H. B. (1954). Journal of Jan van Riebeeck volume II 16561658. Cape Town: The Van Riebeeck Society.

Thom, H. B. (1958). Journal of Jan van Riebeeck volume III 1658-1662. Cape Town: The Van Riebeeck Society.

Thompson, G. (1967). Travels and adventures in southern Africa part 1. Cape Town: The Van Riebeeck Society.

Thompson, G. (1968). Travels and adventures in southern Africa part 2. Cape Town: The Van Riebeeck Society.

Thunberg, C. P. (1986). Travels at the Cape of Good Hope 17721775. Cape Town: Van Riebeeck Society.

Uilenberg, G. (1998). A field guide for the diagnosis, treatment and prevention of African animal trypanosomiasis. Rome: Food and Agriculture Organization of the United Nations.

Valentyn, F. (1971). Description of the Cape of Good Hope part 1. Cape Town: The Van Riebeeck Society.

Valentyn, F. (1973). Description of the Cape of Good Hope part 2. Cape Town: The Van Riebeeck Society.

Van Neer, W., Linseele, V., \& Freidman, R. F. (2004). Animal burials and food offerings at the elite cemetery HK6 of Hierakonpolis. In S. Hendrickx, R. F. Friedman, K. M. Ciałowicz, \& M. Chłodnicki (Eds.), Egypt at its origins: Studies in memory of Barbara Adams (pp. 67-130). Leuven: Peeters.

Van Neer, W., Linseele, V., Freidman, R. F., \& De Cupere, B. (2014). More evidence for cat taming at the Predynastic elite cemetery of Hierakonpolis (Upper Egypt). Journal of Archaeological Science, 45, 103-111. van Sittert, S. J., Drew, T. M., Kotze, J. L., Strydom, T., Weyer, C. T., \& Guthrie, A. J. (2013). Occurrence of African horse sickness in a domestic dog without apparent ingestion of horse meat. Journal of the South African Veterinary Association, 84, 948.

Voigt, E. A. (1983). Mapungubwe: An archaeozoological interpretation of an Iron Age community. Pretoria: Transvaal Museum.

Voigt, E. A. (1986). Iron Age herding: Archaeological and ethnoarchaeological approaches to pastoral problems. South African Archaeological Society Goodwin Series, 5, 13-21.

Voigt, E. A., Plug, I., \& Sampson, C. G. (1995). Acquisition of European livestock by the Seacow River Bushmen between AD 1770-1890. Southern African Field Archaeology, 4, 3749.

von den Driesch, A. (1997). Tierreste aus Buto im Nildelta. Archaeofauna, 6, 23-39.

Watson, E. J., \& Watson, V. (1990). "Of commoners and kings": Faunal remains from Ondini. South African Archaeological Bulletin, 45, 33-46.

Way, K. C. (2011). Donkeys in the Biblical world: Ceremony and symbol. Winona Lake: Eisenbrauns.

Webley, L. (1992). The history and ethnoarchaeology of pastoralist and hunter-gatherer settlement in the north-western Cape, South Africa. PhD dissertation, University of Cape Town.

Welker, F., Soressi, M., Rendu, W., Hublin, J.-J., \& Collins, M. (2015). Using ZooMS to identify fragmentary bone from the Late Middle/Early Upper Palaeolithic sequences of Les Cottés, France. Journal of Archaeological Science, 54, 279-286.

Wilson, M. (1982). The Nguni people. In M. Wilson \& L. Thompson (Eds.), A history of South Africa to 1870 (pp. 75-130). London: Croom Helm.

Wilson, R. T. (2013). The past, present and future of domestic equines in Tanzania. Journal of Equine Science, 24(3), 3745.

Wilson, A., Mellor, P. S., Szmaragd, C., \& Mertens, P. P. C. (2009). Adaptive strategies of African horse sickness virus to facilitate vector transmission. Veterinary Research, 40, 16.

Wise, L. N., Kappmeyer, L. S., Mealey, R. H., \& Knowles, D. P. (2013). Review of equine piroplasmosis. Journal of Veterinary Internal Medicine, 27, 1334-1346. 